\title{
Phosphorylation of eIF2 $\alpha$ Promotes Schwann Cell Differentiation and Myelination in CMT1B Mice with Activated UPR
}

\author{
Cristina Scapin, ${ }^{1}$ Cinzia Ferri, ${ }^{1}$ Emanuela Pettinato, ${ }^{1}$ Francesca Bianchi, ${ }^{2}$ Ubaldo Del Carro, ${ }^{2}$ \\ ${ }^{\circledR}$ M. Laura Feltri, ${ }^{3,4,5}$ Randal J. Kaufman, ${ }^{6}{ }^{\circledR}$ Lawrence Wrabetz, $^{3,4,5}$ and ${ }^{\circledR}$ Maurizio D'Antonio $^{1}$ \\ ${ }^{1}$ Division of Genetics and Cell Biology, San Raffaele Scientific Institute, 20132 Milan, Italy, ${ }^{2}$ Institute of Experimental Neurology, San Raffaele \\ Scientific Institute, 20132 Milan, Italy, ${ }^{3}$ Hunter James Kelly Research Institute, State University of New York at Buffalo, Buffalo, New York 14203, \\ ${ }^{4}$ Department of Neurology, State University of New York at Buffalo, Buffalo, New York 14203, ${ }^{5}$ Department of Biochemistry, Jacob School of \\ Medicine and Biomedical Sciences, State University of New York at Buffalo, Buffalo, New York 14203, and ${ }^{6}$ Degenerative Diseases Program, \\ Sanford Burnham Prebys Medical Discovery Institute, La Jolla, California, California 92130
}

Myelin Protein Zero (MPZ/P0) is the most abundant glycoprotein of peripheral nerve myelin. P0 is synthesized by myelinating Schwann cells, processed in the endoplasmic reticulum (ER) and delivered to myelin via the secretory pathway. The mutant P0S63del (deletion of serine 63 in the extracellular domain of P0), that causes Charcot-Marie-Tooth type 1B (CMT1B) neuropathy in humans and a similar demyelinating neuropathy in transgenic mice, is instead retained the ER where it activates an unfolded protein response. Under ER-stress conditions, protein kinase R-like endoplasmic reticulum kinase (PERK) phosphorylates eukaryotic initiation factor $2 \alpha$ (eIF $2 \alpha)$ to attenuate global translation, thus reducing the misfolded protein overload in the ER. Genetic and pharmacological inactivation of Gadd34 (damage-inducible protein 34), a subunit of the PP1 phosphatase complex that promotes the dephosphorylation of eIF2 $\alpha$, prolonged eIF $2 \alpha$ phosphorylation and improved motor, neurophysiological, and morphologic deficits in S63del mice. However, PERK ablation in S63del Schwann cells ameliorated, rather than worsened, S63del neuropathy despite reduced levels of phosphorylated eIF $2 \alpha$. These contradictory findings prompted us to genetically explore the role of eIF $2 \alpha$ phosphorylation in P0S63del-CMT1B neuropathy through the generation of mice in which eIF2 $\alpha$ cannot be phosphorylated specifically in Schwann cells. Morphologic and electrophysiological analysis of male and female S63del mice showed a worsening of the neuropathy in the absence of eIF2 $\alpha$ phosphorylation. However, we did not detect significant changes in ER stress levels, but rather a dramatic increase of the MEK/ERK/c-Jun pathway accompanied by a reduction in expression of myelin genes and a delay in Schwann cell differentiation. Our results support the hypothesis that eIF2 $\alpha$ phosphorylation is protective in CMT1B and unveil a possible cross talk between eIF $2 \alpha$ and the MEK/ERK pathway in neuropathic nerves.

Key words: eIF2 $\alpha$; ER stress; myelin; neuropathy; Schwann cell; UPR

Significance Statement

In the P0S63del (deletion of serine 63 in the extracellular domain of P0) mouse model of Charcot-Marie-Tooth type 1B (CMT1B), the genetic and pharmacological inhibition of Gadd34 (damage-inducible protein 34) prolonged eukaryotic initiation factor $2 \alpha$ $(\mathrm{eIF} 2 \alpha)$ phosphorylation, leading to a proteostatic rebalance that significantly ameliorated the neuropathy. Yet, ablation of protein kinase R-like endoplasmic reticulum kinase (PERK) also ameliorated the S63del neuropathy, despite reduced levels of eIF2 $\alpha$ phosphorylation (P-eIF2 $\alpha$ ). In this study, we provide genetic evidence that eIF2 $\alpha$ phosphorylation has a protective role in CMT1B Schwann cells by limiting ERK/c-Jun hyperactivation. Our data support the targeting of the P-eIF2 $\alpha /$ Gadd34 complex as a therapeutic avenue in CMT1B and also suggest that PERK may hamper myelination via mechanisms outside its role in the unfolded protein response.

Received Apr. 23, 2020; revised July 9, 2020; accepted July 27, 2020.

Author contributions: L.W. and M.D. designed research; C.S., C.F., E.P., F.B., U.D.C., and M.D. performed research; C.S., C.F., F.B., U.D.C., M.L.F., R.J.K., and M.D. analyzed data; M.D. wrote the paper.

This work was supported by Fondazione Telethon, Italy (Grants GGP14147 and GGP15012 to M.D.) the Italian Ministry of Health (Grant GR-2011-02346791 to M.D.), AFM-Telethon, France (Grant 19968 to M.D.), and the Umberto Veronesi Foundation (Fellowship Award 2014 to C.S.). This work was supported in part by National Institutes of Health Grants R01-CA-198103, R01-DK-113171, and R01-AG-062190 (to R.J.K.). We thank Rosa Mastrangelo, Maria Carla Panzeri, and the Alembic facility at the San Raffaele Scientific Institute for excellent technical support, and Ghjuvan'Ghjacumu Shackleford for help with the artwork. The authors declare no competing financial interests.

Correspondence should be addressed to Maurizio D'Antonio at dantonio.maurizio@hsr.it.

https://doi.org/10.1523/JNEUROSCI.0957-20.2020

Copyright $\odot 2020$ the authors 


\section{Introduction}

Myelin Protein Zero (MPZ/P0) is a transmembrane glycoprotein specifically expressed by myelinating Schwann cells in the peripheral nervous system (PNS), necessary for the adhesion and compaction of adjacent myelin wraps (Filbin et al., 1990; Giese et al., 1992; Shapiro et al., 1996). To date, $>200$ different mutations in $\mathrm{P} 0$ that cause the hereditary neuropathy Charcot-Marie-Tooth 1B (CMT1B) have been identified (Sanmaneechai et al., 2015; Callegari et al., 2019). The vast majority are dominantly inherited and act via gain-of-function mechanisms (Wrabetz et al., 2006). Protein misfolding, accumulation in the endoplasmic reticulum (ER) and activation of the unfolded protein response (UPR) is emerging as a relatively common pathomechanism for P0 mutations (Bai et al., 2018). One such example is the deletion of serine 63 in the extracellular domain of P0 (P0S63del), which causes a CMT1B neuropathy characterized by hypomyelination, progressive demyelination, and onion bulb formation in both humans and transgenic mice (Wrabetz et al., 2006; Pennuto et al., 2008; Miller et al., 2012).

The mammalian UPR is characterized by the activation of the following three distinct ER resident sensors: protein kinase RNA-like ER kinase (PERK) activating transcription factor 6 (ATF6) and inositol-requiring protein $1 \alpha$ (Ire $1 \alpha)$, which together coordinate translational and transcriptional responses aimed at restoring cellular homeostasis (Ron and Walter, 2007). ATF6 induces the expression of ER-resident chaperones to increase the folding capacity of the cell (Haze et al., 1999; Wu et al., 2007; Yamamoto et al., 2007). IRE1 $\alpha$ catalyzes the unconventional splicing of the mRNA for the transcription factor X-box binding protein 1 (Xbp1) to generate the active Xbp1s (Lee et al., 2002), which in turn upregulates the expression of genes involved in ER biogenesis and ER-associated degradation (ERAD; Yoshida et al., 2001; Lee et al., 2003; Acosta-Alvear et al., 2007). Finally, PERK triggers the phosphorylation of the $\alpha$ subunit of eukaryotic initiation factor 2 $(\mathrm{P}$-eIF2 $\alpha)$ at Ser51 to attenuate general protein synthesis (Harding et al., 2000a; Clemens, 2001). At the same time, the phosphorylation of eIF $2 \alpha$ is also responsible for the selective translation of a series of mRNA-containing small upstream open reading frames (Harding et al., 2000b), including the mRNA for ATF4 (Lu et al., 2004), which is proposed to induce prosurvival genes involved in the antioxidant stress response, amino acid synthesis, and protein folding (Scheuner et al., 2001; Harding et al., 2003). However, in conditions of chronic stress ATF4 may lead to cell death via the activation of the proapoptotic factor CHOP (CCAAT-enhancer-binding protein homologous protein)/Gadd153 (damage-inducible protein 153) and of genes involved in protein synthesis (Novoa et al., 2001; Han et al., 2013).

In P0S63del-CMT1B mice, genetic ablation of CHOP ameliorated motor capacity and partially reduced demyelination (Pennuto et al., 2008). We identified growth arrest and DNA damage-inducible protein 34 (Gadd34) as the maladaptive effector of Chop (D'Antonio et al., 2013). Gadd34, also known as PPP1R15a, is a regulatory subunit of protein phosphatase 1 (PP1) holophosphatase that dephosphorylates eIF $2 \alpha$ to reactivate protein translation (Novoa et al., 2001). Genetic and pharmacological inhibition of Gadd34 prolonged eIF2 $\alpha$ phosphorylation, largely ameliorating S63del neuropathy (D'Antonio et al., 2013; Das et al., 2015). Surprisingly, PERK haploinsufficiency or the Schwann cell-specific ablation of PERK ameliorated, rather than aggravated, the S63del neuropathic phenotype, despite reduced levels of P-eIF2 $\alpha$ (Musner et al., 2016; Sidoli et al., 2016)
We thus decided to directly investigate the role of eIF $2 \alpha$ phosphorylation in the P0S63del-CMT1B neuropathy. In this study, we show that the phosphorylation of eIF $2 \alpha$ in S63del Schwann cells is protective. Surprisingly, however, lack of eIF2 $\alpha$ phosphorylation did not significantly alter UPR or oxidative stress levels, but dramatically delayed Schwann cell differentiation and myelination, possibly acting via the MEK/ERK/c-Jun pathway. These findings support the prolonging of eIF $2 \alpha$ phosphorylation as a valid target for therapy in ER stress-related neuropathies and uncover a previously unrecognized cross talk between the UPR and the MEK/ERK pathway.

\section{Materials and Methods}

Transgenic mice. All experiments involving animals were performed in accord with experimental protocols approved by the San Raffaele Scientific Institute Animal Care and Use Committee. P0Cre and S63del mice with relative genotyping procedures have been previously described (Feltri et al., 1999; Wrabetz et al., 2006). Mice carrying a eIF2 $\alpha$ Ser51Ala mutation (herein S/A if heterozygous and $\mathrm{A} / \mathrm{A}$ if homozygous) and a loxP-flanked wild-type (WT) eIF2 $\alpha$ transgene (fTg) in all tissues (S/A or $\mathrm{A} / \mathrm{A} / / \mathrm{fTg}$ mice), were previously described (Scheuner et al., 2005; Back et al., 2009). We first crossed A/A//fTg transgenic mice with P0Cre mice to generate $\mathrm{S} / \mathrm{A} / / \mathrm{P} 0 \mathrm{Cre}$ mice (eIF2 $\alpha^{\mathrm{SC}-\mathrm{SA}}$ mice). In parallel, we crossed the A/A//fTg with the neuropathic S63del mice to generate S/A//fTg// S63del mice. We then crossed eIF $2 \alpha^{\mathrm{SC}-\mathrm{SA}}$ mice with $\mathrm{S} / \mathrm{A} / / \mathrm{fTg} / / \mathrm{S} 63 \mathrm{del}$ mice to obtain the experimental mice in which eIF $\alpha$ cannot be phosphorylated in Schwann cells (in either wild-type eIF $2 \alpha^{\text {SC-AA }}$ or neuropathic S63del/eIF $2 \alpha^{\text {SC-AA }}$ background; Fig. 1). In all experiments, A/A//fTg [herein control (CTR)] and A/A//fTg//S63del (herein S63del) littermates were used as controls since morphologically indistinguishable from original WT and S63del mice, respectively (data not shown). S63del mice were maintained on the FVB/N background, whereas both P0Cre and A/A// $\mathrm{fTg}$ were on the C57BL/6 genetic background. The analysis of all four experimental genotypes was performed in F1 hybrid background FVB// C57BL6. Mice of either sex were used throughout the study.

Morphologic analysis. Transgenic mice were killed at the indicated time points and sciatic nerves were dissected. Semi-thin section and electron microscope analyses of sciatic nerves, were performed as described (Ferri et al., 2018). The number of amyelinated or demyelinated axons and onion bulbs were counted blind to genotype from postnatal day 21 (P21) or 5-month-old sciatic nerve semi-thin sections (0.5-1 $\mu \mathrm{m}$ thick) stained with toluidine blue, in images taken with a $100 \times$ objective. We analyzed 1000-1800 fibers from a total of 10-20 fields/nerve (five nerves). Ultrathin sections ( $90 \mathrm{~nm}$ thick) from P10 and P21 transgenic and control sciatic nerves were cut using an ultracut ultramicrotome, stained with uranyl acetate and lead citrate, and were examined by electron microscopy (EM; Leo 912 Omega). G-ratio analysis (axonal diameter/fiber diameter) and the size distribution of myelinated fibers (based on axon diameter) were measured on digitalized nonoverlapping electron micrograph images. Twenty to 25 microscopic fields, randomly chosen, from nerves of three to four animals per genotype were analyzed.

TaqMan quantitative PCR analysis. Sciatic nerves from transgenic mice were frozen in liquid nitrogen after dissection. Total RNA from at least three sciatic nerves for each genotype was extracted using TRIzol (Roche Diagnostic) and reverse transcription was performed as described previously (D'Antonio et al., 2006). Quantitative RT-PCR was performed according to manufacturer instructions (TaqMan, Thermo Fisher Scientific) on an ABI PRISM 7700 sequence detection system (Thermo Fisher Scientific). Normalization was performed using $18 \mathrm{~S}$ rRNA as reference gene. Target and reference gene PCR amplification was performed in separate tubes with Assay on Demand (Thermo Fisher Scientific): $18 \mathrm{~S}$ assay Hs99999901_s1; MPZ assay Mm00485141_m1; PMP22 assay Mm01333393_m1; myelin basic protein (MBP) assay Rn00690431_m1; Ddit3/Chop, Mm00492097_m1; Xbp-1u assay, Mm00457357_m1; Xbp1s assay, Mm03464496_ml; Hspa5/BiP (Ig binding protein) assay, Mm00517691_m1; Egr2/Krox20 assay, ATF4 assay, Mm00515324_m1; Id2 assay, Mm00711781_m1; Sox2 assay, Mm00488369_m1; JUN assay, Mm00495062_m1; POU3F1/Oct6 assay, Mm00843534_m1; 
Hmox1 assay, Mm00516005_m1; Gpx1 assay, Mm00656767_g1; and Gss assay, Mm00515065_m1.

Protein extraction and Western blotting. Sciatic nerves from transgenic mice, at the indicated time points, were dissected and frozen in liquid nitrogen. Protein extraction and protein content analysis were previously described (Wrabetz et al., 2006). The following rabbit polyclonal antibodies were used: Grp78/Bip (1:1000; catalog \#NB300-520, Novus Biologicals; RRID:AB_10011084); phospho-Akt (Ser473; 1:1000; catalog \#9271, Cell Signaling Technology; RRID:AB_329825) and AKT (1:1000; catalog \#9272, Cell Signaling Technology; RRID:AB_329827); and phospho-ERK1/2 (Thr202/Tyr204) and ERK1 (1:1000; catalog \#9101, Cell Signaling Technology; RRID:AB_331646), and ERK2 (1:1000; catalog \#9102, Cell Signaling Technology; RRID:AB_330744, respectively). Rabbit monoclonal antibodies recognized PeIF2 $\alpha$ (Ser51; D9G8) XPTM (1:2000; catalog \#3398, Cell Signaling Technology; RRID:AB_ 2096481; and eIF2 $\alpha$ (D7D3) XPTM (catalog \#5324, Cell Signaling Technology; RRID: AB_10692650); and c-Jun (1:1000; catalog \#9165, Cell Signaling Technology; RRID:AB_ 2130165). Mouse monoclonal antibody recognized ATF4/Creb2 (B-3; 1:100, Santa Cruz Biotechnology, sc-390063), EGFP (1:2000, Abcam, ab127417, RRID:AB_11129790) and $\beta$-tubulin (1:2000; Sigma, T4026, RRID:AB_ 477577). Peroxidase-conjugated secondary antibodies anti-mouse horseradish peroxidase (HRP; catalog \# P0260, DAKO; RRID:AB_2636929) and anti-rabbit HRP (catalog \#P0448, DAKO; RRID:AB_2617138) were diluted 1:3000, and results were visualized using GE Healthcare ECL or ECL Prime 225 reagent (GE Healthcare) for highsensitivity chemiluminescent protein detection with UVItec gel analysis systems. Densitometric quantification was performed with ImageJ.

Detection of oxidized proteins. Protein concentration of sciatic nerve extracts was measured using the BCA Protein Assay Kit (Thermo Fisher Scientific). A reducing agent (1\%, 2-mercaptoethanol) was added to the extracts to prevent the oxidation of proteins that may occur after cell lysis. A total amount of $15 \mu \mathrm{g}$ of protein per sample, was derivatized with a twofold volume of 2,4-dinitrophenylhydrazine (DNPH) solution or derivatization control solution (Oxyblot Protein Oxidation Detection Kit, EMD Millipore) as described in the protocol. Proteins were separated by SDS-PAGE. The gels containing DNPH-derivatized proteins were transferred to a nitrocellulose membrane ( $250 \mathrm{~mA}$ for $2 \mathrm{~h}$ ) and subsequently blocked for $1 \mathrm{~h}$ with $1 \%$ BSA in PBS-T buffer (PBS with $0.5 \%$ Tween-20). Oxyblots were incubated with a rabbit anti-dinitrophenyl primary antibody $(1: 150)$ overnight at $4^{\circ} \mathrm{C}$ Membranes were washed three times with PBS-T buffer and incubated for $1 \mathrm{~h}$ with an anti-rabbit IgG2a HRP-conjugated secondary antibody diluted 1:300 (both $1^{\circ}$ and $2^{\circ}$ antibodies from Oxyblot Protein Oxidation Detection Kit, EMD Millipore) and developed using the ECL method, as described above.

Immunofluorescence. Sciatic nerves from P21 transgenic mice were dissected, embedded in optimal cutting temperature compound, and frozen in liquid nitrogen. Eight-micrometer-thick transverse sections (model CM1850_UV Cryostat, Leica) were fixed for $10 \mathrm{~min}$ in 4\% PFA, rinsed and permeabilized with cold methanol; samples were then blocked with antibody blocking solution [ADS (10\% NGS, 1\% BSA in PBS $1 \times$ )] for $1 \mathrm{~h}$. The following primary antibodies were diluted in ADS and incubated overnight at $4^{\circ} \mathrm{C}$ : rat anti-MBP (1:10 culture medium 233 of hybridoma cells; a gift from Judith Grinspan Department of Neurology, The Children's Hospital of Philadelphia, Philadelphia, Pennsylvania); and rabbit anti-EGFP (1:100; catalog \#A11122, Thermo Fisher Scientific; RRID:AB_221569). Goat anti rat Cy3TM-coniugated (catalog \#112166062, Jackson ImmunoResearch;
RRID:AB_2338254) and donkey anti rabbit Alexa Fluor 488-coniugated (catalog \#711545152, Jackson ImmunoResearch; RRID:AB 2313584) were used 1:200 as secondary antibodies. The samples were viewed with a Leica DM5000 microscope, and images were acquired with a Leica DFC480 digital camera and processed with Adobe Photoshop CS4 (Adobe Systems).

Electrophysiological analyses. The electrophysiological evaluation was performed on five to nine mice/genotype at 5 months of age with a specific EMG system (Neuro-Mep-Micro, Neurosoft), as previously described (Biffi et al., 2004). Mice were anesthetized with trichloroethanol $0.02 \mathrm{ml} / \mathrm{g}$ body weight ( $25-30 \mathrm{~g})$ and placed under a heating lamp to maintain constant body temperature. Sciatic nerve conduction velocity (NCV) was obtained by stimulating the nerve with steel monopolar needle electrodes. A pair of stimulating electrodes was inserted subcutaneously near the nerve at the ankle. A second pair of electrodes was placed at the sciatic notch to obtain two distinct sites of stimulation, proximal and distal along the nerve. Compound motor action potential was recorded with a pair of needle electrodes; the active electrode was inserted in muscles in the middle of the paw, whereas the reference was placed in the skin between the first and second digit. Sciatic nerve Fwave latency (FWL) measurement was obtained by stimulating the nerve at the ankle and recording the responses in the paw muscle, with the same electrodes used for the NCV study.

Experimental design and statistical analysis. No statistical methods were used to predetermine sample sized, but our sample sizes are similar to those generally used in the field. Graphs and data were generated and analyzed using GraphPad Prism Software. Data show the mean \pm SEM. Student's $t$ test (two tailed, unpaired) or one-way ANOVA with Bonferroni's multiple-comparison post hoc test were used as indicated. Significance levels were marked on figures as follows: ${ }^{*} p \leq 0.05,{ }^{* *} p \leq 0.01,{ }^{* * *} p \leq 0.001$.

\section{Results}

P0Cre-driven deletion of the floxed WT eIF $2 \alpha$ transgene impedes eIF $2 \alpha$ phosphorylation in Schwann cells

To directly study the effects of the inactivation of eIF $2 \alpha$ phosphorylation in Schwann cells, we crossed mice in which eIF2 $\alpha$ 
A
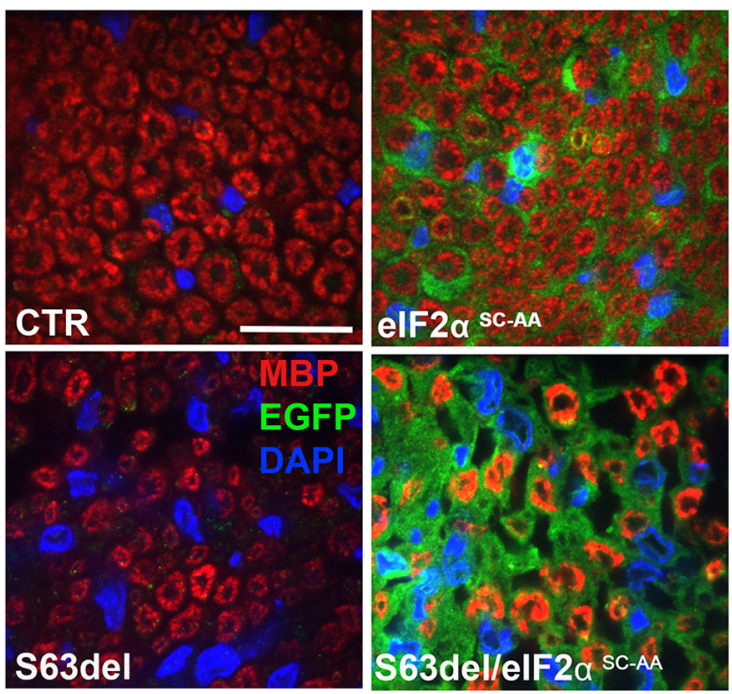

C
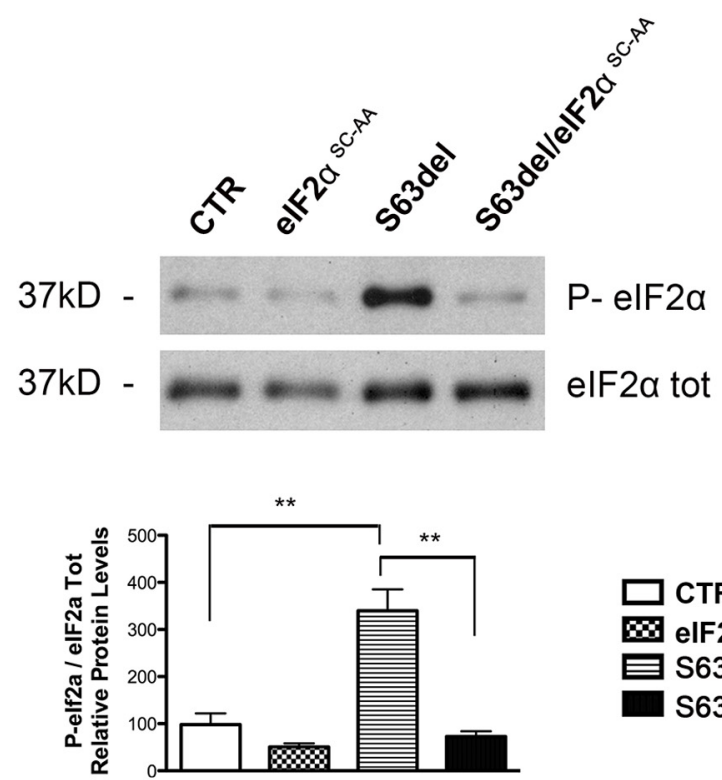

B

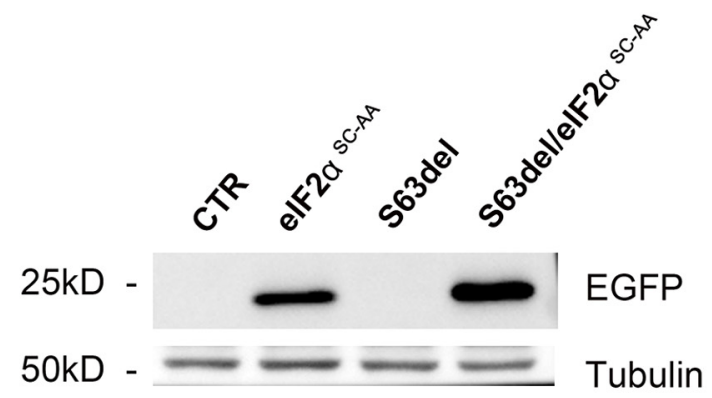

D

37 kD -
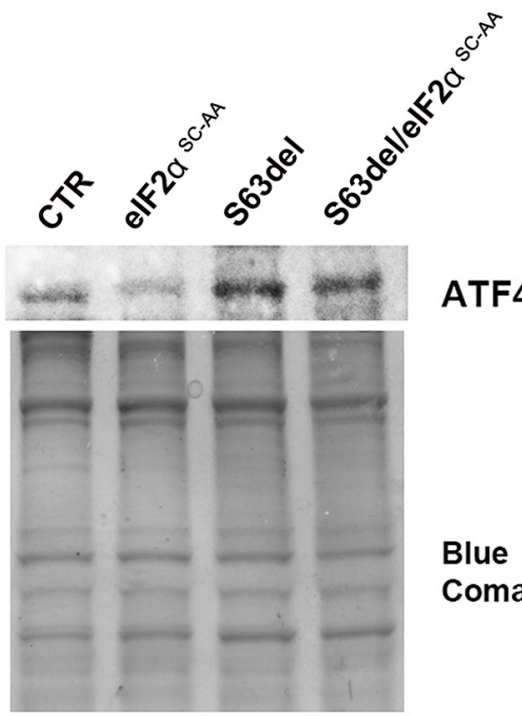

ATF4

Blue

Comassie

Figure 2. Conditional inactivation of elF $2 \alpha$ phosphorylation in Schwann cells. A, Immunofluorescence analysis on P21 sciatic nerves transversal cryosections. MBP (red) was used to visualize myelin; EGFP (green) marks the excision of the WT elF2 $\alpha$ coding sequence. Schwann cell nuclei are stained with DAPI (blue). Scale bar, $20 \mu \mathrm{m}$. $\boldsymbol{B}$, Western blot analysis of P21 sciatic nerve lysates for EGFP; tubulin was used as a loading control. C, Western blot analysis of sciatic nerve lysates from P21 sciatic nerves to evaluate elF $2 \alpha$ phosphorylation. One representative blot of three (quantified in the graph) is shown. $\boldsymbol{D}$, Western blot analysis on sciatic nerve lysates from P21 sciatic nerves for ATF4; Coomassie staining was used to show equal loading. One representative blot of four (quantified in the graph) is shown. ${ }^{*} p \leq 0.05,{ }^{* *} p \leq 0.01,{ }^{* * *} p \leq 0.001$ by Student's $t$ test.

cannot be phosphorylated because of a conditional homozygous eIF2 $\alpha$ Ser51Ala mutation (AA//fTg mice; Back et al., 2009) with P0Cre mice (Feltri et al., 1999). The resulting mice (eIF2 $\alpha^{\mathrm{SC}-\mathrm{AA}}$ ) were then crossed with P0S63del-CMT1B mutant mice (S63del; Wrabetz et al., 2006) to generate S63del/eIF $2 \alpha^{\text {SC-AA }}$ mice for testing the role of eIF $2 \alpha$ phosphorylation in neuropathic nerves with activated UPR (Fig. $1 A$ ). The floxed WT eIF2 $\alpha$ transgene (fTg) was designed to induce green fluorescence protein (EGFP) expression on Cre-mediated deletion of the eIF $2 \alpha$ coding region (Back et al., 2009; Fig. 1B). Immunostaining analysis for MBP and EGFP on P21 sciatic nerve transverse sections confirmed the specificity of the P0Cre-mediated excision of the $\mathrm{fTg}$ transgene followed by induction of EGFP expression in the Schwann cells of both eIF $2 \alpha^{\text {SC-AA }}$ and S63del/eIF2 $\alpha^{\text {SC-AA }}$ mice (Fig. $2 A$ ). The S63del/eIF $2 \alpha^{\text {SC-AA }}$ nerve sections appeared compromised, as shown by reduced and disorganized myelinated fibers compared with S63del and WT (CTR) controls (Fig. 2A). Western blot (WB) analysis on P21 sciatic nerve lysates confirmed that EGFP expression was confined to Cre-expressing nerves (Fig. $2 B$ ) and that P-eIF2 $\alpha$, which as expected was strongly increased in S63del nerves compared with WT (D'Antonio et al., 2013), was almost completely impeded in S63del/eIF $2 \alpha^{\text {SC-AA }}$ mice (Fig. $2 C$ ). The weak P-eIF $2 \alpha$ signal still visible in the eIF $2 \alpha^{\text {SC-AA }}$ and S63del/ eIF $2 \alpha^{\text {SC-AA }}$ samples was probably because of the presence of cell types other than Schwann cells (e.g., fibroblasts, endothelial cells, resident macrophages) in the sciatic nerve, that do not undergo recombination.

Under ER stress conditions, eIF2 $\alpha$ phosphorylation results in global translation attenuation, and in the concomitant selective translation of ATF4 mRNA (Harding et al., 2000b; Scheuner et 
A

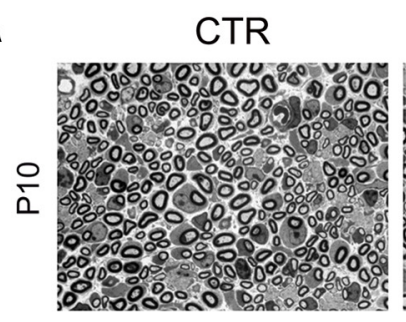

B

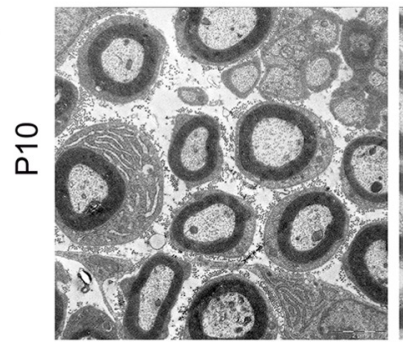

C
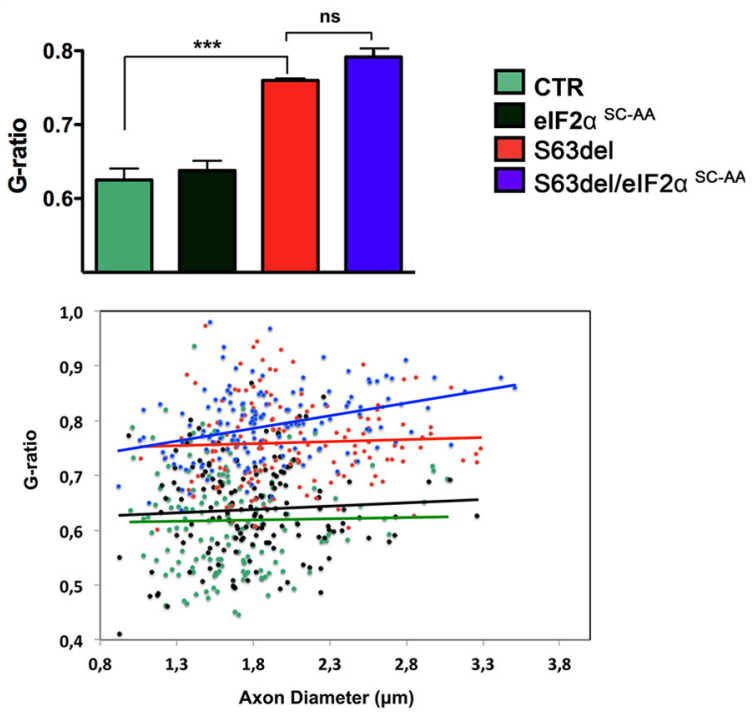

elF2 $\alpha$ Sc-AA
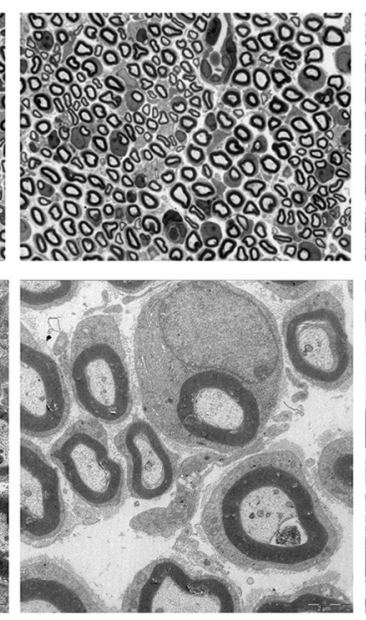

S63del/elF2 $\alpha$ SC-AA
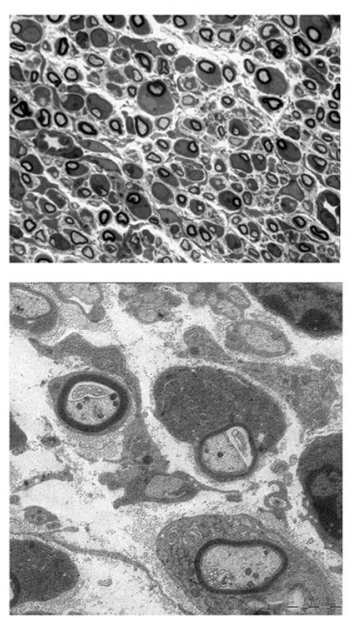

D

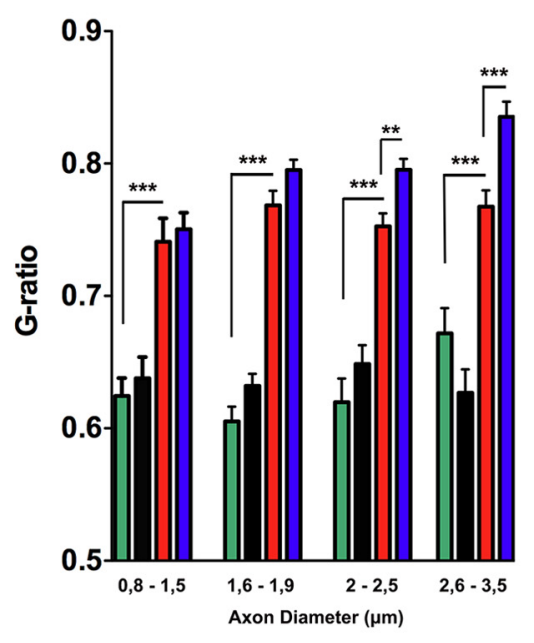

Figure 3. Lack of elF $2 \alpha$ phosphorylation in Schwann cells mildly affects S63del myelination at P10. $\boldsymbol{A}, \boldsymbol{B}$, Transverse semi-thin cross sections (scale bar, $20 \mu \mathrm{m} ; \boldsymbol{A}$ ) and electron microscopy tomography (EM; scale bar, $2 \mu \mathrm{m} ; \boldsymbol{B}$ ) of sciatic nerves at P10. C, G-ratio analysis performed on sciatic nerve EM cross sections at P10 shown as average g-ratio values (top) or scatterplot toward axon diameter (bottom); n.s., not significant; ${ }^{* * *} p \leq 0.001$ by one-way ANOVA. $\boldsymbol{D}$, Average g-ratio plotted by axon diameter; 150 fibers/nerve were analyzed, $n=3$ mice/genotype. ${ }^{* *} p \leq$ $0.01,{ }^{* * *} p \leq 0.001$ by one-way ANOVA.

al., 2001; Harding et al., 2003). The evaluation of translational rates in sciatic nerves in vivo is extremely difficult (D'Antonio et al., 2013). Thus, as a direct measure of the P-eIF $2 \alpha$ downstream cascade, we assessed ATF4 protein levels. ATF4 was increased in S63del nerve extracts but returned toward control levels in S63del/eIF $2 \alpha^{\text {SC-AA }}$ (Fig. $2 D$ ), confirming the inactivation of the pathway. Collectively, these results affirm that the P0Cre recombination system removes the floxed eIF $2 \alpha$-WT fTg transgene abolishing eIF $2 \alpha$ phosphorylation specifically in Schwann cells.

The genetic ablation of eIF $2 \alpha$ phosphorylation in Schwann cells severely affects the dysmyelinating phenotype of S63del nerves

We previously showed that in S63del nerves the phosphorylation of eIF $2 \alpha$ is highly induced during the active phase of myelination, between P10 and P30 (Musner et al., 2016). This therefore represents a good time frame to directly examine the effects of the absence of eIF $2 \alpha$ phosphorylation in Schwann cells. Transverse semi-thin cross sections on P10 sciatic nerves confirmed a reduction in myelination extent in S63del nerves compared with CTR nerves (Wrabetz et al., 2006), but we could not detect any striking difference in S63del/eIF $2 \alpha^{\text {SC-AA }}$ compared with S63del mice (Fig. 3A). A more detailed morphometric analysis performed with EM (Fig. $3 B$ ), however, revealed a mild increase in g-ratio in S63del/eIF $2 \alpha^{\text {SC-AA }}$ compared with neuropathic S63del nerves (g-ratio average values: CTR, $0.625 \pm 0.015$; eIF $2 \alpha^{\text {SC-AA }}, 0.638 \pm 0.013 ;$ S63del, $0.760 \pm 0.002 ;$ S63del/ eIF $2 \alpha^{\text {SC-AA }}, 0.792 \pm 0.011$; Fig. $2 C$ ), which was statistically significant when restricted to axon with a diameter $>2 \mu \mathrm{m}$ (Fig. 3D)

We next looked at P21, a time that roughly corresponds to the peak of ER stress in S63del nerves (D'Antonio et al., 2013). At this time point, the phenotype in S63del/eIF $2 \alpha^{\mathrm{SC}-\mathrm{AA}}$ nerves appeared remarkably compromised, with a severe worsening in hypomyelination compared with S63del. Conversely, the inactivation of eIF $2 \alpha$ phosphorylation in a wild-type background $\left(\right.$ eIF $\left.2 \alpha^{\text {SC-AA }}\right)$ did not affect sciatic nerve morphology, at either $\mathrm{P} 10$ or P21, despite the highly secretory nature of Schwann cells 


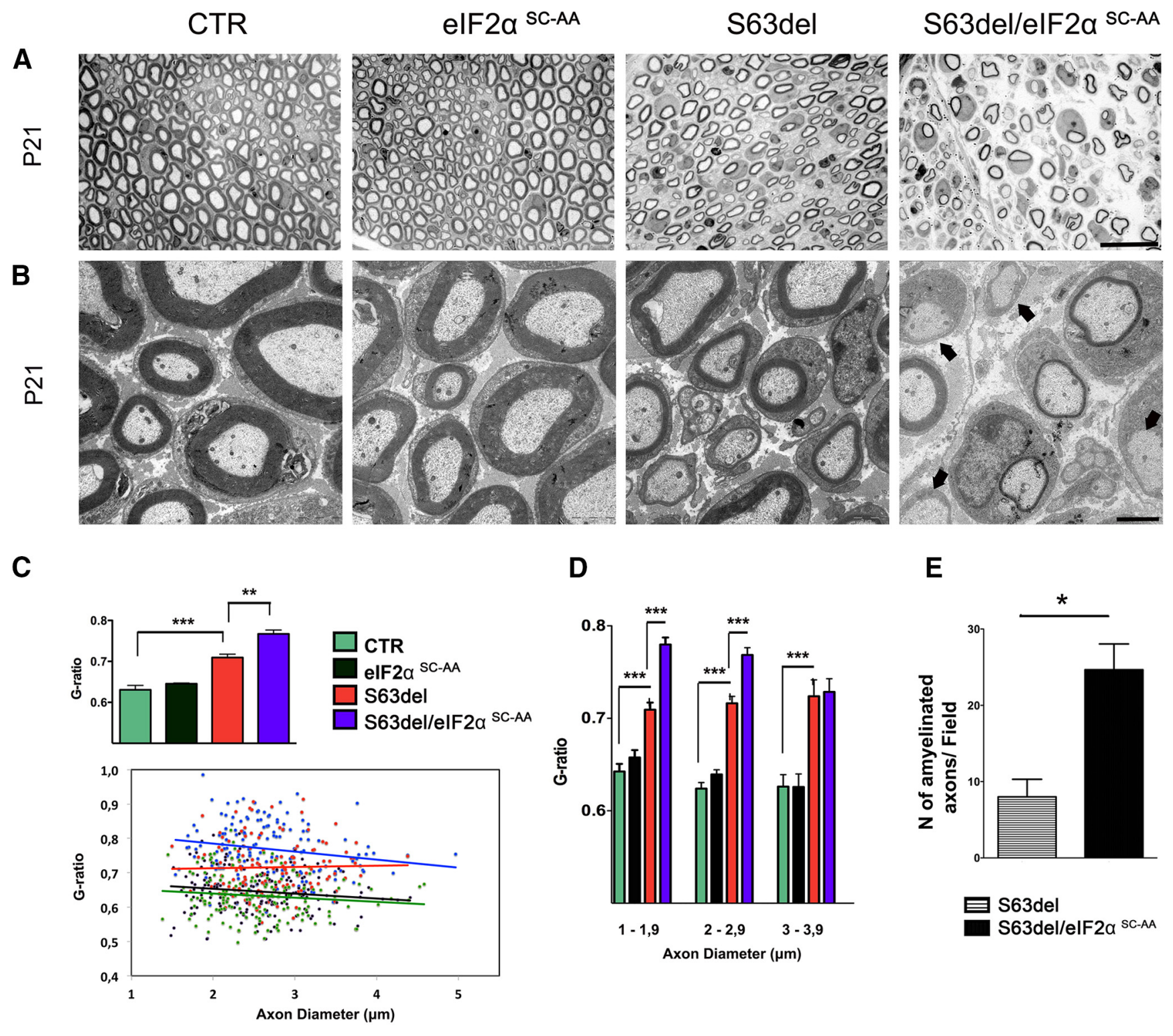

$\mathbf{F}$

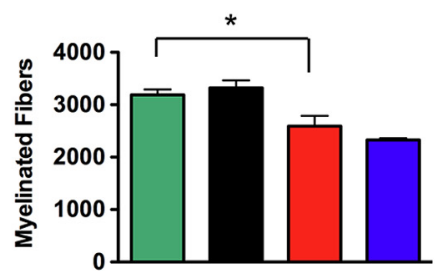

G

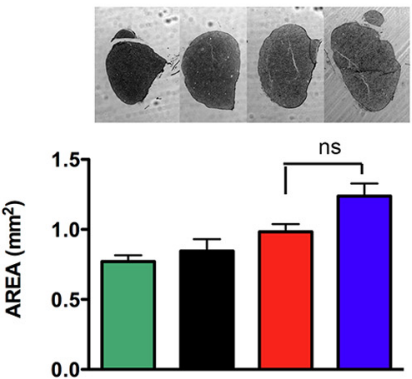

H

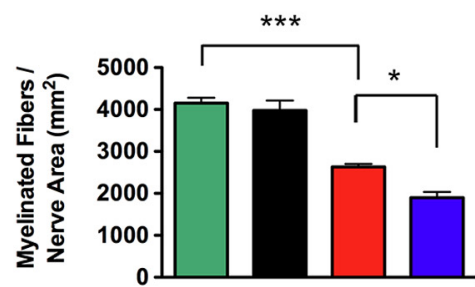

Figure 4. The genetic ablation of P-elF2 $\alpha$ in Schwann cells leads to a severe worsening of the dysmyelinating phenotype in 3-week-old S63del nerves. $\boldsymbol{A}, \boldsymbol{B}$, Transverse semi-thin cross sections $(\boldsymbol{A})$ and EM sections (scale bar, $2 \mu \mathrm{m} ; \boldsymbol{B}$ ) of P21 sciatic nerves. Arrows, Amyelinated fibers. $\boldsymbol{C}$, G-ratio analysis performed on sciatic nerve EM cross sections at P21. Top, Average g-ratio; bottom, g-ratio scatterplot on axon diameter (scatter plot). ${ }^{* *} p \leq 0.01,{ }^{* * *} p \leq 0.001$ by one-way ANOVA. $\boldsymbol{D}$, Average g-ratio plotted by axon diameter; $130-170$ fibers/mouse were analyzed, $n=3$ mice/genotype. ${ }^{* * *} p \leq 0.001$ by one-way ANOVA. $\boldsymbol{E}$, Quantification of amyelinated axons per EM field (black arrows, as in $\boldsymbol{B}$ ) in P21 sciatic nerves; $n=3$ mice/genotype. ${ }^{*} p \leq 0.05$ by Student's $t$ test. $\boldsymbol{F}$, Total number of myelinated fibers per sciatic nerve semi-thin cross sections at P21. $\boldsymbol{G}$, Total area (in $\mathrm{mm}^{2}$ ) of sciatic nerves semi-thin cross sections at P21 (n.s., not significant by one-way ANOVA; $n=3$ nerves/genotype). $\boldsymbol{H}$, Quantification of myelinated fibers density; ${ }^{*} p<0.05$, ${ }^{* * *} p<0.001$ by one-way ANOVA; $n=3$ nerves/genotype.

(Figs. 3A, 4A). EM analysis confirmed the reduction in myelin thickness in S63del/eIF $2 \alpha^{\mathrm{SC}-\mathrm{AA}}$ mice, as measured by g-ratio analysis (Fig. $4 B, C$; g-ratio: CTR, $0.631 \pm 0.011$; eIF $2 \alpha^{\text {SC-AA }}$, $0.645 \pm 0.002 ;$ S63del, $0.709 \pm 0.008 ;$ S $63 \mathrm{del} / \mathrm{eIF} 2 \alpha^{\mathrm{SC}-\mathrm{AA}}, 0.767 \pm$ 0.010 ). This reduction appeared to be mostly restricted to axons with a diameter up to $3 \mu \mathrm{m}$ (Fig. $4 D$ ). Moreover, we detected a threefold increase in amyelinated fibers (axons with diameter $>1 \mu \mathrm{m}$ blocked in a 1:1 relationship with a Schwann cell) in S63del/eIF2 $\alpha^{\text {SC-AA }}$ compared with S63del sciatic nerves (Fig. $4 B$, $E)$, accompanied by a small reduction in the total number of 
A
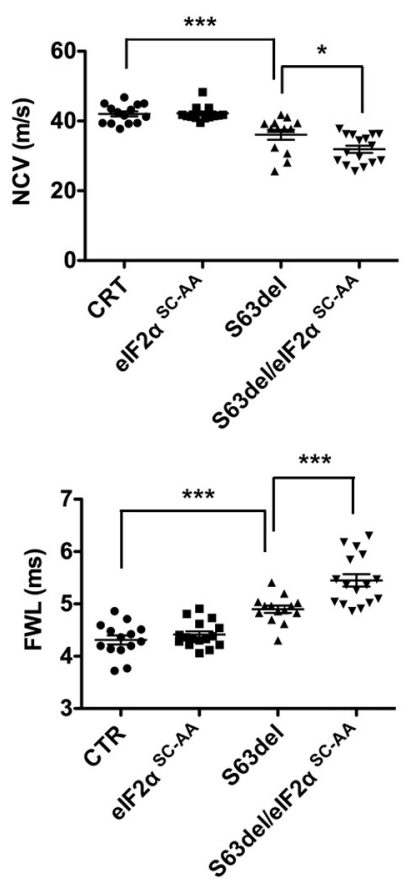

B

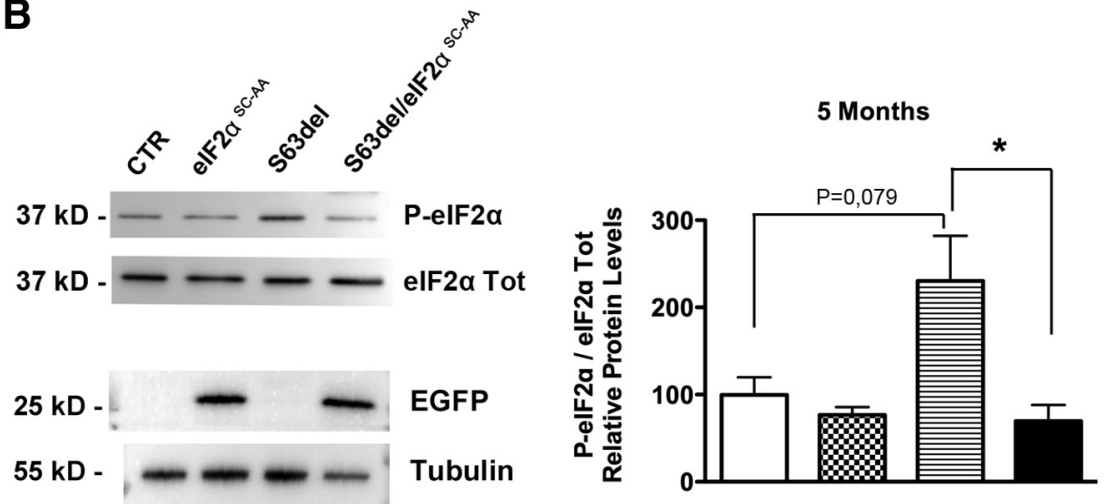

C

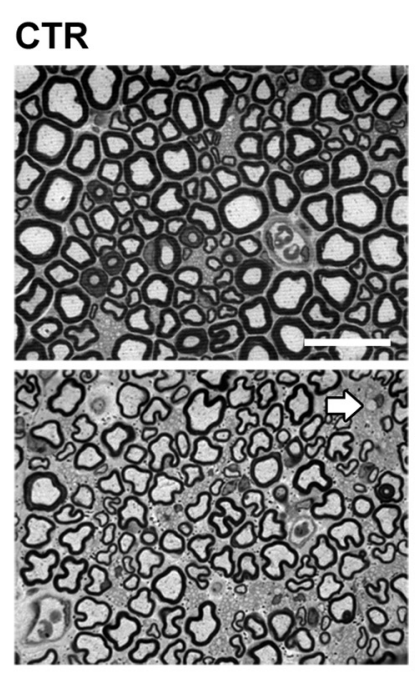

S63del
elF2 $\alpha$ sc-AA
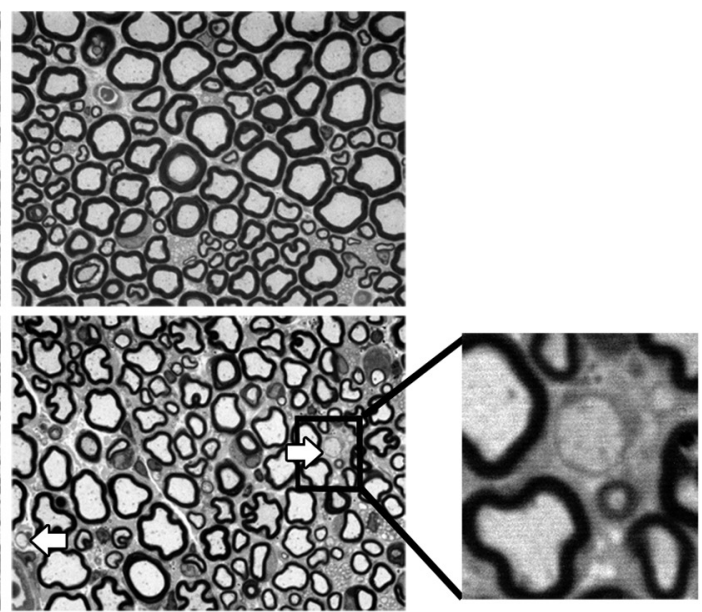

S63del/elF2 $\alpha$ SC-AA

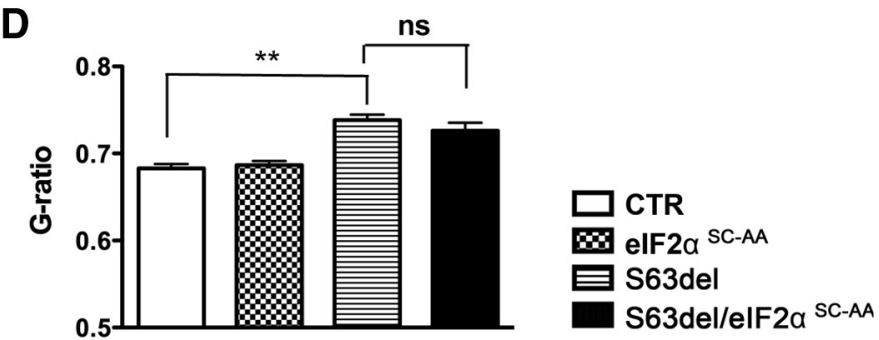

E

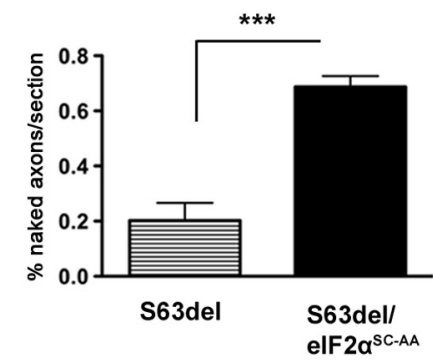

Figure 5. The genetic ablation of P-elF2 $\alpha$ in Schwann cells worsens neurophysiological parameters in adult S63del mice. A, Analysis of NCV (top) and FWL (bottom) in 5-month-old mice. $N=7-10$ animals/genotype. Data represent the mean $\pm \mathrm{SEM} ;{ }^{*} p \leq 0.05,{ }^{* * *} p \leq 0.001$ by one-way ANOVA. $\boldsymbol{B}$, Western blot analysis of 5 -month-old sciatic nerve lysates for P-elF2 $\alpha$ and EGFP; tubulin was used as a loading control. One representative blot of three (quantified in the graph) is shown. ${ }^{*} p \leq 0.05$ by Student's $t$ test. $C$, Sciatic nerves semi-thin cross sections from 5-month-old CTR, elF $2 \alpha^{\text {SCAA }}$, S63del, and S63del/elF $2 \alpha^{\text {SCAA }}$ mice. White arrow and inset show a demyelinated fiber. $\boldsymbol{D}, \mathrm{G}$-ratio analysis, ${ }^{* *} p \leq 0.01$ by one-way ANOVA, n.S., not significant. $E$, Quantification of naked axons; ${ }^{* * *} p \leq 0.001$ by Student's $t$ test. $N=3$ mice/genotype.

myelinated axons per nerve section (Fig. 4F). Concomitantly, the nerve section area was increased in S63del/eIF $2 \alpha^{\text {SC-AA }}$ compared with S63del sciatic nerves (CTR, $0.77 \pm 0.045$; eIF $2 \alpha^{\mathrm{SC}-\mathrm{AA}}, 0.84 \pm$ 0.08; S63del, $0.98 \pm 0.05$; S63del/eIF $2 \alpha^{\text {SC-AA }}, 1.24 \pm 0.09 \mathrm{~mm}^{2}$; Fig. $4 G)$. As a result, the relative myelinated fiber density was significantly reduced in S63del/eIF2 $\alpha^{\text {SC-AA }}$ (in fibers $/ \mathrm{mm}^{2}$; CTR, $4151.7 \pm 127.7$; eIF $2 \alpha^{\mathrm{SC}-\mathrm{AA}}, 3978.2 \pm 238.4$; S63del, $2630.3 \pm 72.6$; S63del/eIF2 $\alpha^{\text {SC-AA }}, 1900 \pm 134.7$; Fig. $\left.4 A, H\right)$.

Collectively, these data indicate that, despite being dispensable for normal PNS myelination, the phosphorylation of $\operatorname{eIF} 2 \alpha$ is a protective event in developing CMT1B-S63del neuropathic Schwann cells. These results corroborate previous observations showing that the inhibition of eIF $2 \alpha$ dephosphorylation ameliorated S63del myelination (D’Antonio et al., 2013; Das et al., 2015).
Lack of eIF2 $\alpha$ phosphorylation in Schwann cells worsens neurophysiology and demyelination in S63del mice Adult S63del mice manifest reduced NCV, increased FWL, and progressive demyelination, similar to the alterations found in patients (Wrabetz et al., 2006; Miller et al., 2012). To test how the genetic ablation of eIF $2 \alpha$ phosphorylation would affect these features, we performed neurophysiological analysis on mice at 5 months of age. We confirmed a significant alteration of NCV and FWL in S63del mice compared with control mice (Wrabetz et al., 2006); S63del/eIF $2 \alpha^{\text {SC-AA }}$ showed a further impairment of these parameters (Fig. 5A). Yet, this worsening was somehow less dramatic than we anticipated based on the severe phenotype observed in S63del/eIF2 $\alpha^{\text {SC-AA }}$ sciatic nerves at P21, despite the fact that also at 5 months P-eIF $2 \alpha$ was increased in S63del nerves 
A

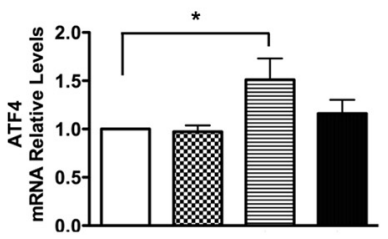

B

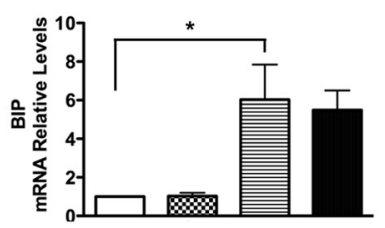

D
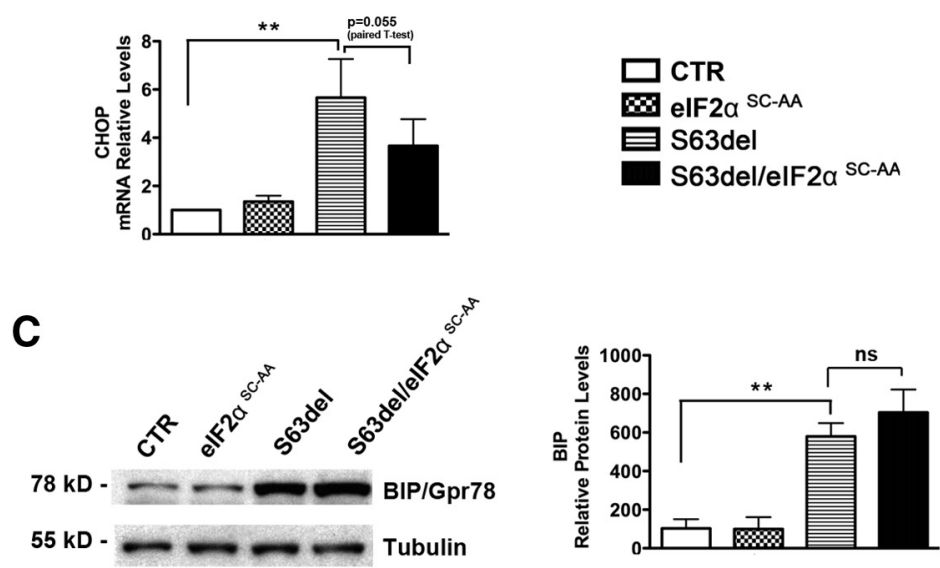
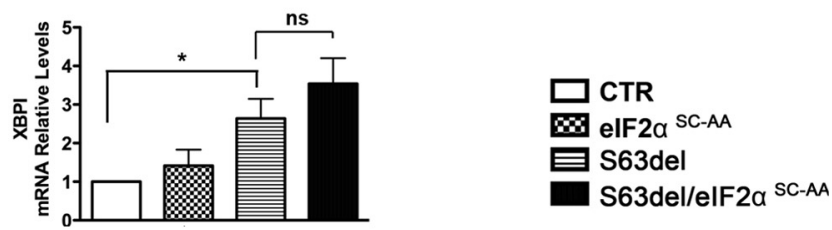

Figure 6. Ablation of P-elF $2 \alpha$ does not alter the UPR in S63del nerves. $A, B, q R T-P C R$ analysis of P21 sciatic nerve extracts for the UPR factors ATF4, CHOP, and BiP; $n=3-5$ reverse transcriptions (RTs) from independent pools of nerves. Values are expressed as the fold change compared with WT. C, Western blot analysis on P21 sciatic nerve extracts for the ER stress marker $\mathrm{BiP} / \mathrm{Gpr} 78$; one representative blot of three (quantified in the graph) is shown. $\boldsymbol{D}$, qRT-PCR analysis on P21 sciatic nerve extracts for the UPR factor Xbp1s; $n=3-5$ RTs from independent pools of nerves. Values are expressed as the fold change compared with WT. ${ }^{*} p \leq 0.05$ and ${ }^{* *} p \leq 0.01$ by one-way ANOVA, n.s., not significant.

compared with CTR (although to a lesser extent compared with P21) and impeded in S63del/eIF2 $\alpha^{\text {SC-AA }}$ (Fig. 5B). We therefore performed both morphologic and morphometric analysis on adult nerves to investigate how lack of eIF $2 \alpha$ phosphorylation was affecting myelin maintenance. Similar to what we observed at P21, 5-month-old eIF2 $\alpha^{\mathrm{SC}-\mathrm{AA}}$ nerves did not show any appreciable difference compared with control nerves, whereas S63del nerves were clearly hypomyelinated. Surprisingly, S63del/ eIF $2 \alpha^{\text {SC-AA }}$ nerves recovered myelin thickness to levels comparable to those of S63del mice (Fig. $5 C$ ), as measured by g-ratio analysis on transverse semi-thin cross sections (CTR, $0.683 \pm$ 0.005; eIF2 $\alpha^{\text {SC-AA }}, 0.687 \pm 0.005$; S63del, $0.738 \pm 0.006$; S63del/ eIF $2 \alpha^{\text {SC-AA }}, 0.726 \pm 0.009$; Fig. $5 D$ ); on the other hand, S63del/ eIF $2 \alpha^{\text {SC-AA }}$ nerves still displayed a significantly increased number of naked axons (which could represent either amyelinated or demyelinated axons) compared with S63del (Fig. 5C,E). These observations suggest that, although phosphorylation of eIF2 $\alpha$ may be dispensable for S63del nerves to eventually reach their maximal myelin thickness, it is still necessary to promote myelination of all axons and to protect Schwann cells from demyelination. The increase in naked axons may also explain why S63del/ eIF $2 \alpha^{\text {SC-AA }}$ still showed impaired neurophysiology compared with S63del.

\section{Ablation of eIF $2 \alpha$ phosphorylation does not exacerbate the UPR or oxidative stress in S63del nerves}

Our data indicate that in S63del Schwann cells the lack of eIF2 $\alpha$ phosphorylation is highly detrimental in particular during the phase of active myelination, when S63del nerves experience the maximal induction of the UPR (D'Antonio et al., 2013; Musner et al., 2016). We reasoned that unabated mRNA translation and lack of ATF4 downstream target activation in S63del/eIF $2 \alpha^{\text {SC-AA }}$ nerves might lead to excessive production and accumulation of mutant P0S63del in the ER with consequent exacerbation of the
UPR. Indeed, mice that express higher levels of P0S63del (S63del-H mice; Wrabetz et al., 2006) or mice with increased accumulation of P0S6del in the ER because of ERAD inefficiency (Volpi et al., 2019) show augmented UPR and a very severe phenotype, not dissimilar from what seen in S63del/eIF $2 \alpha^{\mathrm{SC}-\mathrm{AA}}$ nerves.

We thus analyzed the activation state of the three arms of the UPR in sciatic nerves lysates from S63del/eIF $2 \alpha^{\text {SC-AA }}$ and littermate control mice at P21. Quantitative real-time PCR (qRTPCR) showed that the mRNA levels of ATF4 and its downstream target CHOP (PERK/eIF2 $\alpha$ pathway of the UPR) were significantly increased in S63del compared with WT mice (Pennuto et al., 2008; D'Antonio et al., 2013). In S63del/eIF $2 \alpha^{\text {SC-AA }}$, ATF4 returned toward WT levels, whereas $\mathrm{CHOP}$, although reduced compared with S63del, was still partially elevated (Fig. 6A) possibly because CHOP can be activated also through the ATF6 branch of the UPR (Li et al., 2000; Yoshida et al., 2000). As a measure of ATF6 and Ire1 pathway activation, we evaluated the levels of their targets BiP/Grp78 and spliced Xbp1 (Xbp1s), respectively (Bertolotti et al., 2000; Yoshida et al., 2001; Lee et al., 2003). BiP/Gpr78 mRNA and protein, as well as the levels of the mRNA for Xbpls were increased in S63del nerves compared with WT controls (Wrabetz et al., 2006; Pennuto et al., 2008; D'Antonio et al., 2013), but we did not detect any significant change in the absence of eIF $2 \alpha$ phosphorylation in Schwann cells (Fig. $6 B-D$, respectively). Overall, these data suggested that the genetic ablation of eIF2 $\alpha$ phosphorylation results in worsening of the S63del-CMT1B nerve phenotype, yet without further intensifying the toxic gain of function mechanism.

Studies performed in pancreatic and hepatic cells have shown how deficiency of eIF $2 \alpha$ phosphorylation can lead to cell death induced by oxidative damage (Back et al., 2009; Choi et al., 2017), possibly because of the role of ATF4 in maintaining cellular redox homeostasis (Harding et al., 2003; Lange et al., 2008). 
Hence, to explore the possibility of an ROS cytotoxic effect also in S63del/ eIF $2 \alpha^{\text {SC-AA }}$ sciatic nerves, we measured the mRNAs levels of a subset of ROS defense genes. The mRNA levels of both GPX1, a hydrogen peroxidescavenging enzyme, and Hemy-oxygenase-1 (HO-1), a NADPH-dependent antioxidant enzyme, did not show any relevant difference in eIF $2 \alpha^{\mathrm{SC}-\mathrm{AA}}$ compared with WT mice, and Glutatione S-transferase (GSS) levels were actually significantly increased (Fig. $7 A$ ). GSS levels were also slightly increased in S63del nerves along with GPX1 levels, but we did not detect any difference in the expression of these antioxidant enzymes between S63del and S63del/eIF2 $\alpha^{\text {SC-AA }}$ mice (Fig. $7 A$ ). Next, we tested for the presence of carbonylated proteins, a largely used oxidative stress biomarker, via Western blot immunoassay. This analysis did not reveal differences in the general redox status among the four genotypes (Fig. $7 B$ ), overall indicating that the genetic ablation of eIF $2 \alpha$ phosphorylation in Schwann cells does not lead to a detrimental oxidative stress.

\section{The deficiency of eIF $2 \alpha$}

phosphorylation leads to a delay in

Schwann cell differentiation that may involve the MEK/ERK/c-Jun pathway

Our data showed that S63del/eIF2 $\alpha^{\mathrm{SC}-\mathrm{AA}}$ Schwann cells did not experience either exacerbation of the UPR or a significant activation of oxidative stress. On the other hand, previous work on pancreatic cells had also implicated eIF $2 \alpha$ phosphorylation in controlling cell differentiation (Back et al., 2009).

Schwann cell differentiation and myelination are regulated by a precise balancing between positive and negative transcriptional regulators (Jessen and Mirsky, 2008), and CMT1B-S63del Schwann cells are maintained in a limited differentiation state, characterized by sustained expression of a series of negative regulators that preserve their viability (D'Antonio et al., 2013; Florio et al., 2018). We thus wondered whether lack of eIF $2 \alpha$ phosphorylation could interfere with this finely tuned equilibrium. To test this hypothesis, we first analyzed the mRNA expression of a panel of genes related to Schwann cell development. The mRNAs for the myelin proteins MBP and PMP22, which are slightly decreased in S63del compared with control, appeared further decreased in S63del/eIF2 $\alpha^{\text {SC-AA }}$ (Fig. 8A). Of note, the levels of MPZ mRNA also appeared to be decreased, although not significantly, in S63del/eIF $2 \alpha^{\text {SC-AA }}$ nerves.

Next, we checked the transcript levels of Krox20/Egr2, one of the master regulators of myelination (Topilko et al., 1994; Parkinson et al., 2004), which appeared roughly unchanged between S63del and CTR sciatic nerves, but then slightly decreased in S63del/eIF2 $\alpha^{\mathrm{SC}-\mathrm{AA}}$ (Fig. 8B). Intriguingly, the levels of Oct6, a crucial transcription factor involved in the transition from promyelinating to myelinating Schwann cells (Jaegle et al., 1996), previously shown to be increased in S63del nerves (Florio et al., 2018), was further increased in S63del/eIF $2 \alpha^{\mathrm{SC}-\mathrm{AA}}$ nerves (Fig. 8B), suggesting defects in Schwann cell differentiation. We therefore examined the levels of several known negative regulators of myelination such as c-Jun, Sox2, and Id2 (Le et al., 2005; Parkinson et al., 2008; Fazal et al., 2017; Florio et al., 2018). We confirmed that all of them were upregulated in S63del sciatic nerves (D'Antonio et al., 2013; Florio et al., 2018), but, while we did not observe any further changes in Sox 2 and Id2 mRNA levels (Fig. 8C), we detected a significant increase in c-Jun mRNA and protein levels in S63del/eIF2 $\alpha^{\text {SC-AA }}$ compared with S63del nerves (Fig. $8 D$ ). In peripheral nerves, c-Jun is a downstream target of the MEK/ERK pathway (Napoli et al., 2012), and activation of MEK/ERK signaling is sufficient to drive myelin gene downregulation, Schwann cell dedifferentiation, and demyelination in adult nerves (Harrisingh et al., 2004; Napoli et al., 2012). Indeed, WB analysis of P21 sciatic nerves detected a striking increase of ERK1/2 phosphorylation in S63del/eIF2 $\alpha^{\mathrm{SC}-\mathrm{AA}}$ nerves, whereas $\mathrm{P}-\mathrm{AKT}^{(\mathrm{Ser} 473)}$ activity, which is known to also control Schwann cell myelination (Ogata et al., 2004; Domènech-Estévez et al., 2016), was not affected (Fig. 9A). Of note, imbalance between AKT and ERK1/2 phosphorylation levels was suggested to contribute to differentiation defects during early postnatal development in neuropathic Schwann cells (Fledrich et al., 2014). Instead, at 5 months of age, phosphoERK1/2 expression in S63del/eIF2 $\alpha^{\text {SC-AA }}$ nerves returned to levels comparable to those of S63del, and a similar trend was observed for c-Jun (Fig. 9B). Altogether, these data suggest a complex scenario in which, during the active phase of myelination when ER stress is at its peak, the absence of eIF2 $\alpha$ phosphorylation in S63del Schwann cells determines a dramatic 
A

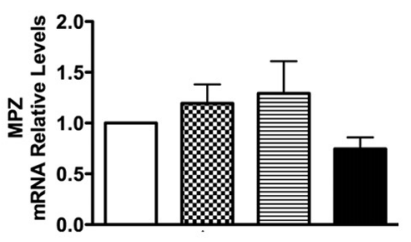

B

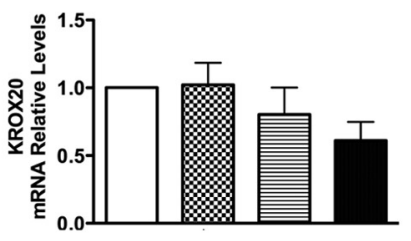

C
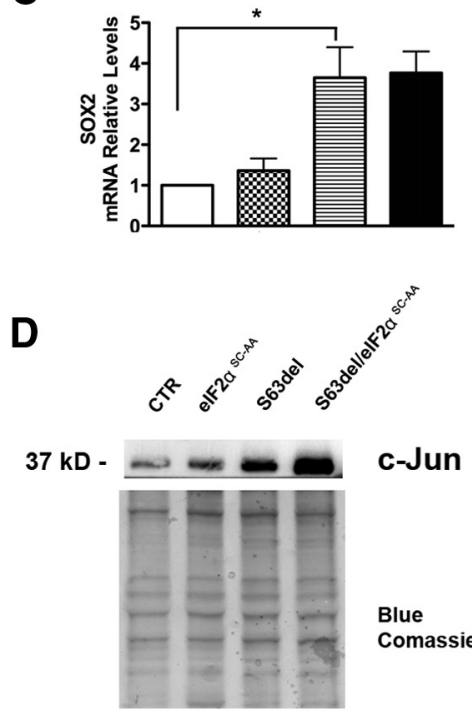
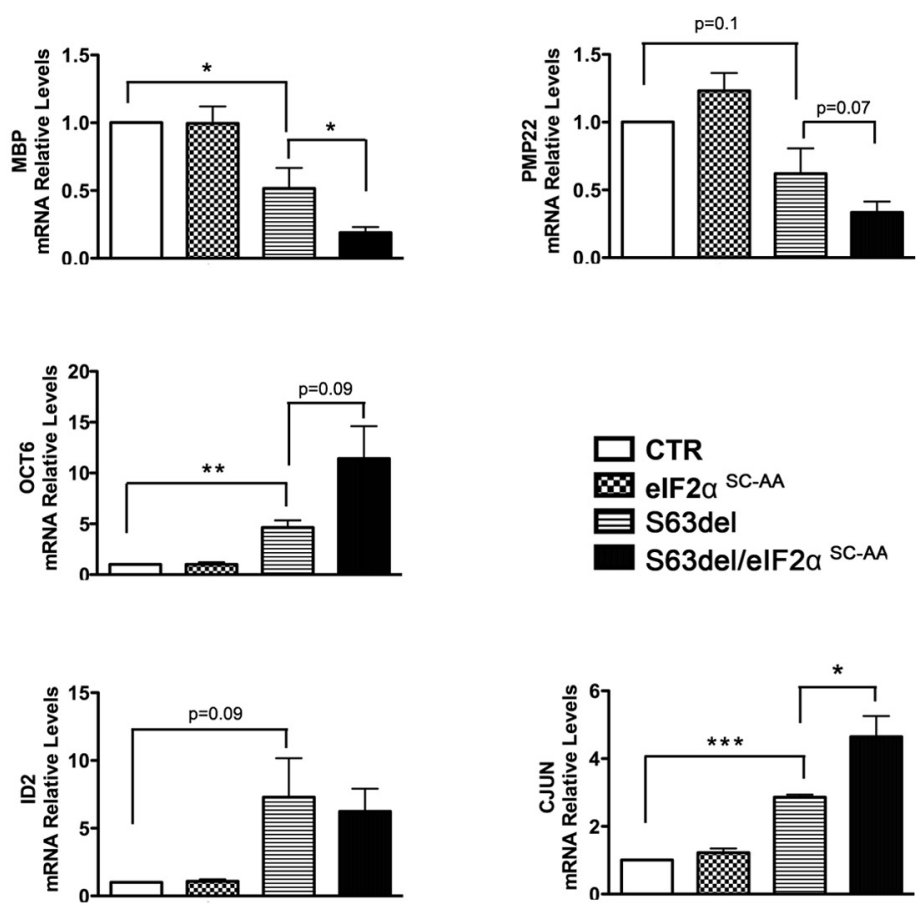

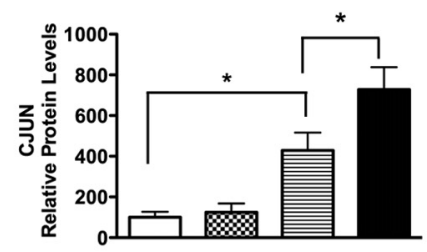

Figure 8. The conditional ablation of elF2 $\alpha$ phosphorylation leads to a delay of Schwann cell differentiation. $A, B$, QRT-PCR analysis of P21 sciatic nerve extracts for the myelin genes MPZ, MBP, and PMP22 ( $\boldsymbol{A})$ and for the transcription factors Krox20/Egr2 and 0ct6/Pou3f1 (B). C, qRT-PCR analysis of P21 sciatic nerve extracts for the negative regulators of myelination Sox2, Id2, and c-Jun. Values are expressed as the fold change compared with WT. Error bars represent the SEM; $n=5$ reverse transcriptions from independent pools of nerves. ${ }^{*} p \leq 0.05,{ }^{* *} p \leq 0.01$, and ${ }^{* *} p<0.001$ by Student's $t$ test. $\boldsymbol{D}$, Western blot analysis on P21 sciatic nerve extracts for c-Jun. One representative blot of three (quantified in the graph) is shown. Coomassie staining was used to show equal loading. ${ }^{*} p \leq 0.05$ by one-way ANOVA.

differentiation delay that is probably mediated by the hyperactivation of the MEK/ERK/c-Jun pathway. In adult S63del nerves, the overall reduction in ER stress (D'Antonio et al., 2013; Fig. $5 B$ ) drives MEK/ERK/c-Jun expression toward basal levels even in the absence of eIF $2 \alpha$ phosphorylation, allowing S63del/ eIF $2 \alpha^{\text {SC-AA }}$ nerves to complete myelination to a degree similar to that in S63del.

\section{Discussion}

Protein misfolding and activation of the UPR is emerging as a common mechanism in CMT1B and several other myelin disorders (Volpi et al., 2017; Bai et al., 2018; Lin and Stone, 2020). Pharmacological inhibition of eIF $2 \alpha$ dephosphorylation alleviated disease manifestations in S63del-CMT1B mice (D'Antonio et al., 2013; Das et al., 2015), making small molecules that prolong eIF2 $\alpha$ phosphorylation appealing therapeutic candidates (Das et al., 2015; Krzyzosiak et al., 2018). Unexpectedly, the ablation of PERK also ameliorated S63del neuropathy, despite reduction in P-eIF2 $\alpha$ (Musner et al., 2016; Sidoli et al., 2016), highlighting the need to fully understand the role of eIF $2 \alpha$ phosphorylation in CMT1B. Here we show that P-eIF2 $\alpha$ is required in S63del Schwann cells to preserve myelination, which appears uncoupled from exacerbated UPR or oxidative stress but may depend on the hyperactivation of the MEK/ERK/c-Jun pathway (Fig. 10).

The phosphorylation of eIF2 $\alpha$ is dispensable for Schwann cell development and myelination but is adaptive in CMT1B

Several studies have highlighted the relevance of P-eIF $2 \alpha$ in the physiology of many cell types, including mouse embryonic fibroblasts, pancreatic $\beta$-cells, hepatocytes (Scheuner et al., 2001; Harding et al., 2003; Back et al., 2009; Choi et al., 2017), Paneth cells (Cao et al., 2014), and hippocampal cells (Di Prisco et al., 2014). In these cells, a lack of eIF $2 \alpha$ phosphorylation resulted in suboptimal induction of UPR genes and an increased susceptibility to ER stress and oxidative stress. However, whereas $\beta$-cells lacking eIF2 $\alpha$ phosphorylation undergo apoptosis (Scheuner et al., 2001; Back et al., 2009), Paneth cells are able to proliferate and differentiate in the absence of P-eIF $2 \alpha$ but become more susceptible to infections (Cao et al., 2014), and eIF2 $\alpha$ 

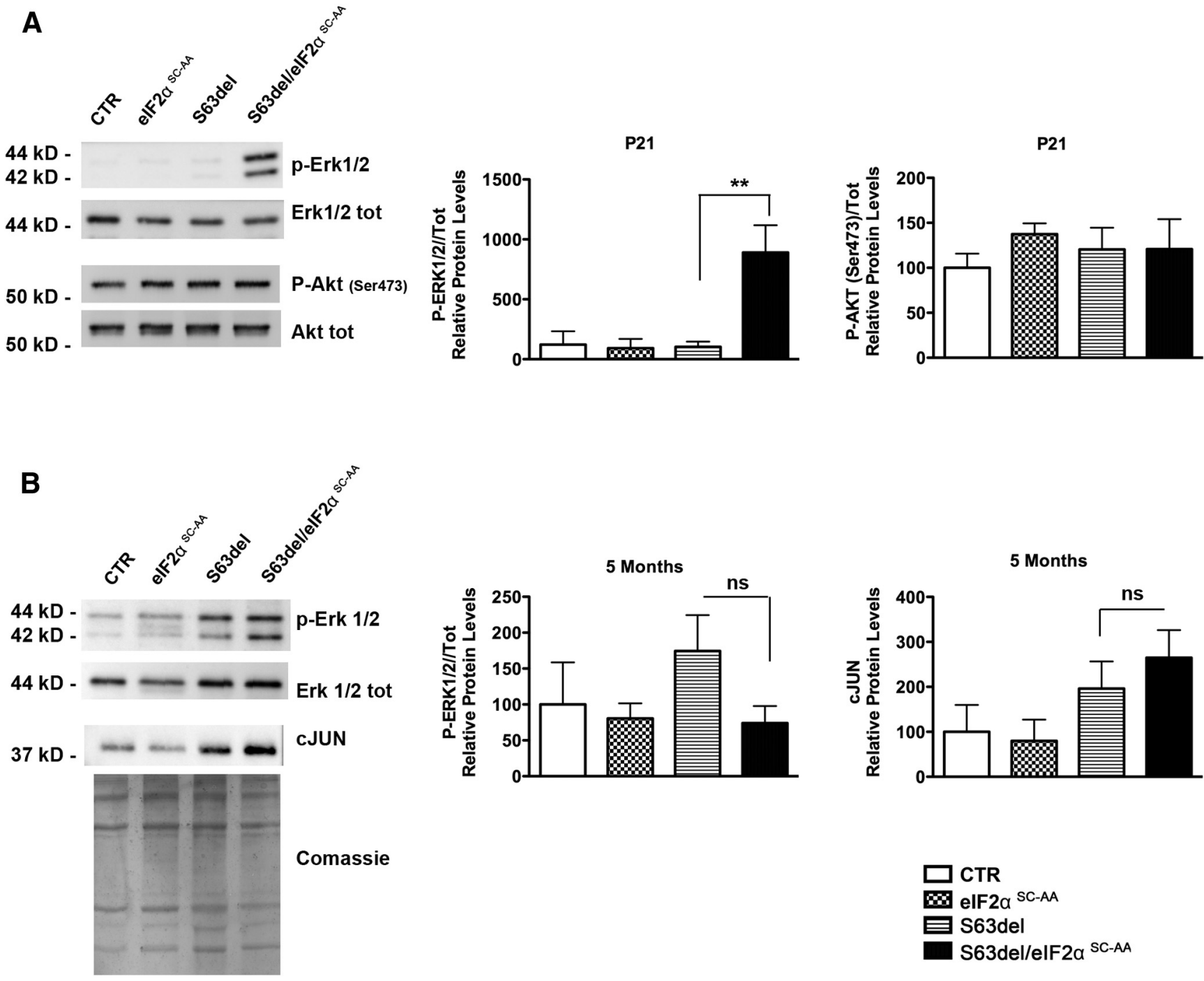

Figure 9. The genetic ablation of elF2 $\alpha$ phosphorylation in S63del nerves hyperactivates the MEK/ERK pathway. $\boldsymbol{A}$, Western blot analysis of P21 sciatic nerves to evaluate Akt ${ }^{\text {(Ser473) }}$ and Erk1/2 phosphorylation. One representative blot of three (quantified in the graph) is shown. ${ }^{* *} p<0.01$ by one-way ANOVA. Error bars represent SEM. $\boldsymbol{B}$, Western blot analysis of 5 -month-old sciatic nerves extract for Erk $1 / 2$ phosphorylation and c-Jun. One representative blot of three is shown. Densitometric quantification is shown in the graph. Coomassie staining was used to show equal loading. Error bars represent the SEM. n.S., Not significant.

phosphorylation-deficient hepatocytes can differentiate but quickly die following challenges with ER stressors (Choi et al., 2017). This indicates some cell- or context-dependent differences in the role of P-eIF2 $\alpha$ in cell viability. Surprisingly, given their highly secretory nature, Schwann cells lacking eIF2 $\alpha$ phosphorylation developed and myelinated normally without displaying signs of altered cellular homeostasis. This adds up to the normal developmental phenotype observed in PERK-null Schwann cells (Sidoli et al., 2016) and in Schwann cells with impaired ERAD (Volpi et al., 2019). Together, these studies suggest that Schwann cells are intrinsically capable of tolerating mild proteostatic fluctuations, presumably by virtue of efficient protein quality control systems and their remarkable plasticity, which allows them to tailor their differentiation state to different conditions (Kim et al., 2013; Volpi et al., 2017; Florio et al., 2018; Jessen and Mirsky, 2019).

However, in stark contrast with the improved phenotype observed in S63del/PERK-null mice (Sidoli et al., 2016), we found that the genetic impediment of eIF $2 \alpha$ phosphorylation is detrimental in myelinating S63del nerves. To the best of our knowledge, this is the first time such a dichotomy in PERK versus P-eIF $2 \alpha$ signaling has been reported. For example, deletion of PERK or the eIF $2 \alpha$ Ser51Ala mutation have similar, although not identical, effects in fibroblasts and $\beta$-cells (Harding et al., 2001; Scheuner et al., 2001; Back et al., 2009; Rajesh et al., 2013). The reasons for this striking difference are not clear, but it should be noted that in S63del/PERK-null and S63del/eIF $2 \alpha^{\text {SC-AA }}$ nerves the UPR levels were unaffected, suggesting that in Schwann cells both P-eIF $2 \alpha$ and PERK may work through pathways other than just the UPR.

The absence of eIF $2 \alpha$ phosphorylation transiently blocks S63del Schwann cell differentiation via the MEK/ERK/c-Jun pathway

In the ER stress condition, P-eIF2 $\alpha$ is required for translational attenuation, UPR gene induction, and cell survival (Harding et al., 2000b; Scheuner et al., 2001, 2005; Back et al., 2009). We reasoned that a lack of P-eIF2 $\alpha$ in S63del Schwann cells could result in excessive accumulation of misfolded protein in the ER. For example, S63del-H mice, expressing higher levels of P0S63del, or S63del Schwann cells lacking the ERAD factor Derlin-2, experience higher ER stress levels and present a very severe 

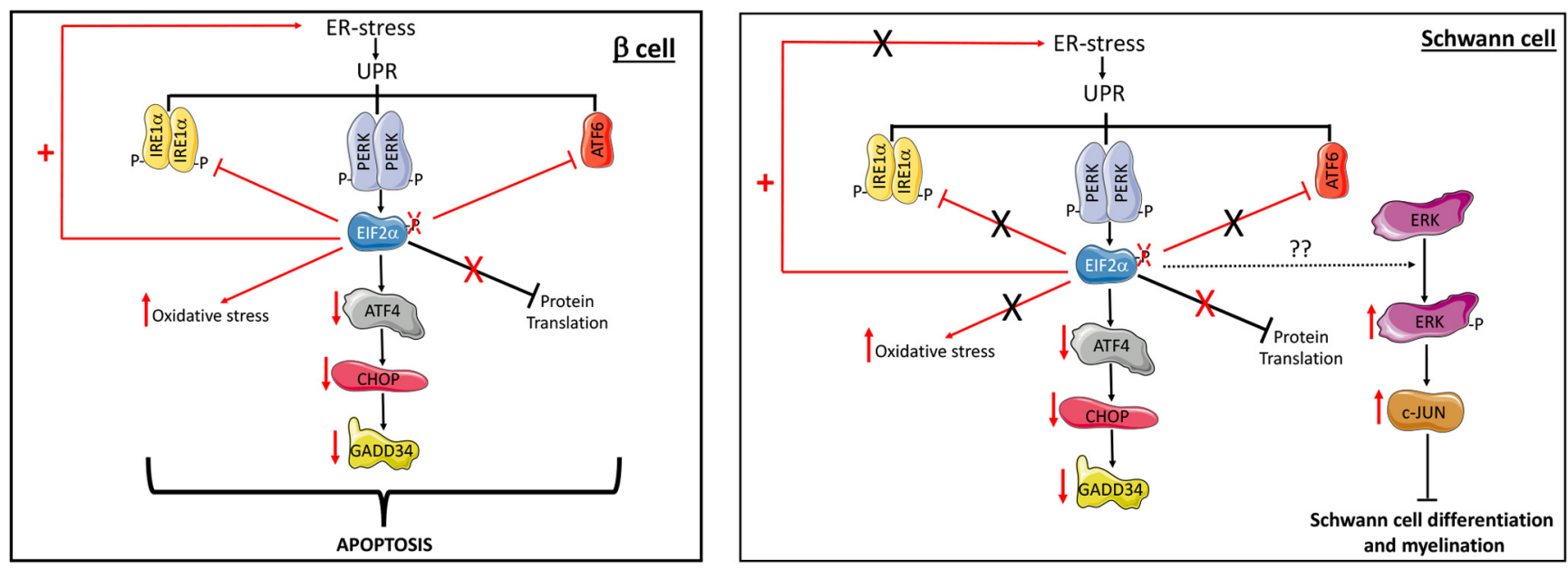

Figure 10. A UPR-independent role for elF2 $\alpha$ phosphorylation in CMT1B Schwann cells. In condition of ER stress, PERK phosphorylates elF2 $\alpha$ to attenuate general protein synthesis. This also leads to the selective translation of the mRNA for the transcription factor ATF4, which in turn activates genes involved in in the antioxidant response and in amino acid metabolism. ATF4 also activates CHOP and Gadd34 (also known as PPP1R15a), which is part of the PP1 holophosphatase complex that dephosphorylates elF2 $\alpha$ to restart protein translation. In most cell types (here epitomized by pancreatic $\beta$-cells), impediment of elF2 $\alpha$ phosphorylation and lack of ATF4 translation leads to a failure to properly activate the UPR pathways governed by IRE1 and ATF6, accumulation of misfolded protein, and increased ER stress and oxidative stress, ultimately resulting in apoptosis. In S63del-CMT1B Schwann cells lacking elF $2 \alpha$ phosphorylation, despite reduced translation of ATF4, the IRE1 and ATF6 pathways of the UPR remain properly activated, and there is no increase in ER stress or oxidative stress. Rather, through an as yet unidentified mechanism, lack of elF $2 \alpha$ phosphorylation determines a hyperactivation of the P-ERK/C-Jun pathway, which in turn disrupts Schwann cell development and myelination.

neuropathic phenotype (Wrabetz et al., 2006; Volpi et al., 2019). Surprisingly, ER stress and UPR levels were unchanged between S63del and S63del/eIF $2 \alpha^{\text {SC-AA }}$ nerves. This is in contrast with what happens in $\beta$-cells, Paneth cells, and hepatocytes (Back et al., 2009; Cao et al., 2014; Choi et al., 2017), where genetic inactivation of eIF $2 \alpha$ phosphorylation results in overall defective UPR signaling and suggests that in Schwann cells P-eIF2 $\alpha$ is not necessary for activation of the UPR (Fig. 10).

In many cell types, $\mathrm{P}$-eIF $2 \alpha$, through the selective translation of ATF4, is essential to protect against oxidative stress. In fibroblasts, $\beta$-cells, and hepatocytes, unrestricted protein translation and lack of ATF4 induction determines an increase in ROS production and a concomitant decrease in antioxidant gene expression, ultimately resulting in cell death (Harding et al., 2003; Back et al., 2009; Cao and Kaufman, 2014; Choi et al., 2017). Here, however, we did not detect alterations in the redox status of eIF $2 \alpha^{\text {SC-AA }}$ nor S63del/eIF $2 \alpha^{\text {SC-AA }}$, despite a reduction in ATF4 expression. Previous studies suggested that Schwann cells display a strong basal antioxidant capacity that allows them to withstand fluctuations in glucose concentrations or mild oxidative stress (Delaney et al., 2001; Vincent et al., 2009). Our data indicate that, most likely, the antioxidant response in Schwann cells is PeIF2 $\alpha$ independent (Fig. 10).

EIF2 $\alpha$ phosphorylation is, however, necessary to promote S63del Schwann cell differentiation and myelination. In particular, Oct6/Pou3f1 and c-Jun were significantly increased in S63del/eIF $2 \alpha^{\text {SC-AA }}$ nerves. Downregulation of Oct6 transcription factor is crucial for the transition from premyelinating to myelinating Schwann cells (Jaegle et al., 1996). Transgenic mice that constitutively expressed Oct6 in Schwann cells were persistently hypomyelinated but showed normal levels of Krox20 mRNA and decreased expression of the major myelin proteins (Ryu et al., 2007). Hypomyelination and reduction in myelin gene expression were also shown in mice expressing high levels of c-Jun in Schwann cells (Fazal et al., 2017). In peripheral nerves, c-Jun is downstream of the ERK signaling pathway (Napoli et al., 2012), and, accordingly, we found a strong elevation of P-ERK1/2 in S63del/eIF2 $\alpha^{\text {SC-AA }}$ nerves. Activation of MEK/ERK/c-Jun is necessary for Schwann cell transdifferentiation to the repair
Schwann cell phenotype after nerve injury (Arthur-Farraj et al., 2012), and strong induction of this pathway is sufficient to block Schwann cell differentiation in vitro or to drive dedifferentiation in adult nerves (Harrisingh et al., 2004; Napoli et al., 2012). The hyperactivation of the MEK/ERK/c-Jun signaling in developing S63del/eIF $2 \alpha^{\text {SC-AA }}$ nerves likely underlies the severe dysmyelination (Fig. 10).

How the inhibition of eIF $2 \alpha$ phosphorylation triggers ERK1/ 2 hyperactivation is unclear. In Schwann cells, moderate ERK1/2 activation downstream of neuregulin-1 (NRG1) type III promotes differentiation and myelination (Newbern et al., 2011). The PI3K/AKT pathway, another crucial mediator of myelination (Goebbels et al., 2010; Domènech-Estévez et al., 2016), also lies downstream of NRG1 type III. Yet, PI3K/AKT is not hyperactivated in our system, making it unlikely that the lack of PeIF2 $\alpha$ hyperactivates ERK1/2 through NRG1. Imbalance in PI3K/AKT and ERK1/2 signaling pathways has been suggested to contribute to Schwann cell differentiation defects in neuropathy (Fledrich et al., 2014) and may therefore also play a role in our system. Several works have also suggested that during ER stress activation of the ERK1/2, mostly through IRE1, represents a prosurvival mechanism (Nguyên et al., 2004; Darling and Cook, 2014). Although we do not see an increase in P-ERK1/2 in S63del nerves, where IRE1 is activated at levels similar to S63del/ eIF $2 \alpha^{\text {SC-AA }}$, we cannot exclude that, in the absence of P-eIF $2 \alpha$, IRE1 may contribute to hyperactivate ERK1/2.

The dysmyelination of S63del/eIF $2 \alpha^{\text {SC-AA }}$ nerves was, however, transient. By 5 months, S63del/eIF $2 \alpha^{\text {SC-AA }}$ nerves had recovered myelination to levels comparable to $\mathrm{S} 63 \mathrm{del}$. This could potentially be explained by the returning of ERK/c-Jun toward S63del levels, which would allow S63del/eIF2 $\alpha^{\text {SC-AA }}$ to proceed with myelination. A similar effect was seen in mice expressing a tamoxifen-inducible Raf/MEK/ERK transgene. Strong induction of ERK led to demyelination and inflammation; once tamoxifen was withdrawn, Schwann cells rapidly redifferentiated and remyelinated axons (Napoli et al., 2012). We speculate that in conditions of strong ER stress, such as those found in myelinating P10-P30 S63del nerves, the lack of P-eIF2 $\alpha$ leads to hyperactivation of P-ERK1/2 and c-Jun, which in turn blocks 
differentiation. In adult S63del mice, ER stress levels are reduced (D'Antonio et al., 2013), as also testified by the reduction in PeIF $2 \alpha$ at 5 months compared with P21 (compare Figs. 2C, $5 B)$. In these conditions, even in the absence of P-eIF $2 \alpha$, ERK1/2 phosphorylation is no longer triggered, allowing S63del/eIF $2 \alpha^{\text {SC-AA }}$ to complete myelination. The generation of transgenic mice in which eIF $2 \alpha$ phosphorylation could be impeded specifically in adulthood would help in addressing this point.

\section{Conclusions}

Our data demonstrate that eIF2 $\alpha$ phosphorylation has a protective role in CMT1B and support its prolonging as a therapeutic option (Das et al., 2015). On the other hand, the phenotypic recovery in adult S63del/eIF $2 \alpha^{\text {SC-AA }}$ also hints that early intervention in CMT1B patients might be preferable. Finally, we also show that, at least in Schwann cells, PERK and P-eIF2 $\alpha$ functions can be uncoupled. How and why the ablation of PERK improves S63del myelination (Sidoli et al., 2016) remains to be explored. The Schwann cell-specific identification of PERK substrates outside of the UPR would represent a first step in this direction.

\section{References}

Acosta-Alvear D, Zhou Y, Blais A, Tsikitis M, Lents NH, Arias C, Lennon CJ, Kluger Y, Dynlacht BD (2007) XBP1 controls diverse cell type- and condition-specific transcriptional regulatory networks. Mol Cell 27:53-66.

Arthur-Farraj PJ, Latouche M, Wilton DK, Quintes S, Chabrol E, Banerjee A, Woodhoo A, Jenkins B, Rahman M, Turmaine M, Wicher GK, Mitter R, Greensmith L, Behrens A, Raivich G, Mirsky R, Jessen KR (2012) c-Jun reprograms Schwann cells of injured nerves to generate a repair cell essential for regeneration. Neuron 75:633-647.

Back SH, Scheuner D, Han J, Song B, Ribick M, Wang J, Gildersleeve RD, Pennathur S, Kaufman RJ (2009) Translation attenuation through eIF2alpha phosphorylation prevents oxidative stress and maintains the differentiated state in beta cells. Cell Metab 10:13-26.

Bai Y, Wu X, Brennan KM, Wang DS, D'Antonio M, Moran J, Svaren J, Shy ME (2018) Myelin protein zero mutations and the unfolded protein response in Charcot Marie Tooth disease type 1B. Ann Clin Transl Neurol 5:445-455.

Bertolotti A, Zhang Y, Hendershot LM, Harding HP, Ron D (2000) Dynamic interaction of $\mathrm{BiP}$ and $\mathrm{ER}$ stress transducers in the unfolded-protein response. Nat Cell Biol 2:326-332.

Biffi A, De Palma M, Quattrini A, Del Carro U, Amadio S, Visigalli I, Sessa M, Fasano S, Brambilla R, Marchesini S, Bordignon C, Naldini L (2004) Correction of metachromatic leukodystrophy in the mouse model by transplantation of genetically modified hematopoietic stem cells. J Clin Invest 113:1118-1129.

Callegari I, Gemelli C, Geroldi A, Veneri F, Mandich P, D’Antonio M, Pareyson D, Shy ME, Schenone A, Prada V, Grandis M (2019) Mutation update for myelin protein zero-related neuropathies and the increasing role of variants causing a late-onset phenotype. J Neurol 266:2629-2645.

Cao SS, Kaufman RJ (2014) Endoplasmic reticulum stress and oxidative stress in cell fate decision and human disease. Antioxid Redox Signal 21:396-413.

Cao SS, Wang M, Harrington JC, Chuang BM, Eckmann L, Kaufman RJ (2014) Phosphorylation of eIF2alpha is dispensable for differentiation but required at a posttranscriptional level for paneth cell function and intestinal homeostasis in mice. Inflamm Bowel Dis 20:712-722.

Choi WG, Han J, Kim JH, Kim MJ, Park JW, Song B, Cha HJ, Choi HS, Chung HT, Lee IK, Park TS, Hatzoglou M, Choi HS, Yoo HJ, Kaufman RJ, Back SH (2017) eIF2 $\alpha$ phosphorylation is required to prevent hepatocyte death and liver fibrosis in mice challenged with a high fructose diet. Nutr Metab (Lond) 14:48.

Clemens MJ (2001) Initiation factor eIF2 alpha phosphorylation in stress responses and apoptosis. Prog Mol Subcell Biol 27:57-89.

D'Antonio M, Michalovich D, Paterson M, Droggiti A, Woodhoo A, Mirsky R, Jessen KR (2006) Gene profiling and bioinformatic analysis of Schwann cell embryonic development and myelination. Glia 53:501-515.

D'Antonio M, Musner N, Scapin C, Ungaro D, Del Carro U, Ron D, Feltri ML, Wrabetz L (2013) Resetting translational homeostasis restores myelination in Charcot-Marie-Tooth disease type 1B mice. J Exp Med 210:821-838.

Darling NJ, Cook SJ (2014) The role of MAPK signalling pathways in the response to endoplasmic reticulum stress. Biochim Biophys Acta 1843:2150-2163.

Das I, Krzyzosiak A, Schneider K, Wrabetz L, D’Antonio M, Barry N, Sigurdardottir A, Bertolotti A (2015) Preventing proteostasis diseases by selective inhibition of a phosphatase regulatory subunit. Science 348:239242.

Delaney CL, Russell JW, Cheng HL, Feldman EL (2001) Insulin-like growth factor-I and over-expression of Bcl-xL prevent glucose-mediated apoptosis in Schwann cells. J Neuropathol Exp Neurol 60:147-160.

Di Prisco GV, Huang W, Buffington SA, Hsu CC, Bonnen PE, Placzek AN, Sidrauski C, Krnjević K, Kaufman RJ, Walter P, Costa-Mattioli M (2014) Translational control of mGluR-dependent long-term depression and object-place learning by eIF2 $\alpha$. Nat Neurosci 17:1073-1082.

Domènech-Estévez E, Baloui H, Meng X, Zhang Y, Deinhardt K, Dupree JL, Einheber S, Chrast R, Salzer JL (2016) Akt regulates axon wrapping and myelin sheath thickness in the PNS. J Neurosci 36:4506-4521.

Fazal SV, Gomez-Sanchez JA, Wagstaff LJ, Musner N, Otto G, Janz M, Mirsky R, Jessen KR (2017) Graded elevation of c-Jun in Schwann cells in vivo: gene dosage determines effects on development, remyelination, tumorigenesis, and hypomyelination. J Neurosci 37:12297-12313.

Feltri ML, D’Antonio M, Previtali S, Fasolini M, Messing A, Wrabetz L (1999) P0-Cre transgenic mice for inactivation of adhesion molecules in Schwann cells. Ann N Y Acad Sci 883:116-123.

Ferri C, Quattrini A, D’Antonio M (2018) Electron microscopy for the analysis of peripheral nerve myelin. Methods Mol Biol 1791:3-13.

Filbin MT, Walsh FS, Trapp BD, Pizzey JA, Tennekoon GI (1990) Role of myelin P0 protein as a homophilic adhesion molecule. Nature 344:871872.

Fledrich R, Stassart RM, Klink A, Rasch LM, Prukop T, Haag L, Czesnik D, Kungl T, Abdelaal TA, Keric N, Stadelmann C, Brück W, Nave KA, Sereda MW (2014) Soluble neuregulin-1 modulates disease pathogenesis in rodent models of Charcot-Marie-Tooth disease 1A. Nat Med 20:10551061.

Florio F, Ferri C, Scapin C, Feltri ML, Wrabetz L, D’Antonio M (2018) Sustained expression of negative regulators of myelination protects Schwann cells from dysmyelination in a Charcot-Marie-Tooth 1B mouse model. J Neurosci 38:4275-4287.

Giese KP, Martini R, Lemke G, Soriano P, Schachner M (1992) Mouse P0 gene disruption leads to hypomyelination, abnormal expression of recognition molecules, and degeneration of myelin and axons. Cell 71:565576.

Goebbels S, Oltrogge JH, Kemper R, Heilmann I, Bormuth I, Wolfer S, Wichert SP, Möbius W, Liu X, Lappe-Siefke C, Rossner MJ, Groszer M, Suter U, Frahm J, Boretius S, Nave KA (2010) Elevated phosphatidylinositol 3,4,5-trisphosphate in glia triggers cell-autonomous membrane wrapping and myelination. J Neurosci 30:8953-8964.

Han J, Back SH, Hur J, Lin YH, Gildersleeve R, Shan J, Yuan CL, Krokowski D, Wang S, Hatzoglou M, Kilberg MS, Sartor MA, Kaufman RJ (2013) ER-stress-induced transcriptional regulation increases protein synthesis leading to cell death. Nat Cell Biol 15:481-490.

Harding HP, Zhang Y, Bertolotti A, Zeng H, Ron D (2000a) Perk is essential for translational regulation and cell survival during the unfolded protein response. Mol Cell 5:897-904.

Harding HP, Novoa I, Zhang Y, Zeng H, Wek R, Schapira M, Ron D (2000b) Regulated translation initiation controls stress-induced gene expression in mammalian cells. Mol Cell 6:1099-1108.

Harding HP, Zeng H, Zhang Y, Jungries R, Chung P, Plesken H, Sabatini DD, Ron D (2001) Diabetes mellitus and exocrine pancreatic dysfunction in perk-/- mice reveals a role for translational control in secretory cell survival. Mol Cell 7:1153-1163.

Harding HP, Zhang Y, Zeng H, Novoa I, Lu PD, Calfon M, Sadri N, Yun C, Popko B, Paules R, Stojdl DF, Bell JC, Hettmann T, Leiden JM, Ron D (2003) An integrated stress response regulates amino acid metabolism and resistance to oxidative stress. Mol Cell 11:619-633.

Harrisingh MC, Perez-Nadales E, Parkinson DB, Malcolm DS, Mudge AW, Lloyd AC (2004) The Ras/Raf/ERK signalling pathway drives Schwann cell dedifferentiation. EMBO J 23:3061-3071.

Haze K, Yoshida H, Yanagi H, Yura T, Mori K (1999) Mammalian transcription factor ATF6 is synthesized as a transmembrane protein and activated 
by proteolysis in response to endoplasmic reticulum stress. Mol Biol Cell 10:3787-3799.

Jaegle M, Mandemakers W, Broos L, Zwart R, Karis A, Visser P, Grosveld F, Meijer D (1996) The POU factor Oct-6 and Schwann cell differentiation. Science 273:507-510.

Jessen KR, Mirsky R (2008) Negative regulation of myelination: relevance for development, injury, and demyelinating disease. Glia 56:1552-1565.

Jessen KR, Mirsky R (2019) The success and failure of the Schwann cell response to nerve injury. Front Cell Neurosci 13:33.

Kim HA, Mindos T, Parkinson DB (2013) Plastic fantastic: Schwann cells and repair of the peripheral nervous system. Stem Cells Transl Med 2:553-557

Krzyzosiak A, Sigurdardottir A, Luh L, Carrara M, Das I, Schneider K, Bertolotti A (2018) Target-based discovery of an inhibitor of the regulatory phosphatase PPP1R15B. Cell 174:1216-1228.e19.

Lange PS, Chavez JC, Pinto JT, Coppola G, Sun CW, Townes TM, Geschwind DH, Ratan RR (2008) ATF4 is an oxidative stress-inducible, prodeath transcription factor in neurons in vitro and in vivo. J Exp Med 205:1227-1242.

Le N, Nagarajan R, Wang JY, Araki T, Schmidt RE, Milbrandt J (2005) Analysis of congenital hypomyelinating Egr2Lo/Lo nerves identifies Sox2 as an inhibitor of Schwann cell differentiation and myelination. Proc Natl Acad Sci U S A 102:2596-2601.

Lee AH, Iwakoshi NN, Glimcher LH (2003) XBP-1 regulates a subset of endoplasmic reticulum resident chaperone genes in the unfolded protein response. Mol Cell Biol 23:7448-7459.

Lee K, Tirasophon W, Shen X, Michalak M, Prywes R, Okada T, Yoshida H, Mori K, Kaufman RJ (2002) IRE1-mediated unconventional mRNA splicing and S2P-mediated ATF6 cleavage merge to regulate XBP1 in signaling the unfolded protein response. Genes Dev 16:452-466.

Li M, Baumeister P, Roy B, Phan T, Foti D, Luo S, Lee AS (2000) ATF6 as a transcription activator of the endoplasmic reticulum stress element: thapsigargin stress-induced changes and synergistic interactions with NF-Y and YY1. Mol Cell Biol 20:5096-5106.

Lin W, Stone S (2020) Unfolded protein response in myelin disorders. Neural Regen Res 15:636-645.

Lu PD, Harding HP, Ron D (2004) Translation reinitiation at alternative open reading frames regulates gene expression in an integrated stress response. J Cell Biol 167:27-33.

Miller LJ, Patzko A, Lewis RA, Shy ME (2012) Phenotypic presentation of the Ser63Del MPZ mutation. J Peripher Nerv Syst 17:197-200.

Musner N, Sidoli M, Zambroni D, Del Carro U, Ungaro D, D’Antonio M, Feltri ML, Wrabetz L (2016) Perk ablation ameliorates myelination in S63del-Charcot-Marie-Tooth 1B neuropathy. ASN Neuro 8: 1759091416642351.

Napoli I, Noon LA, Ribeiro S, Kerai AP, Parrinello S, Rosenberg LH, Collins MJ, Harrisingh MC, White IJ, Woodhoo A, Lloyd AC (2012) A central role for the ERK-signaling pathway in controlling Schwann cell plasticity and peripheral nerve regeneration in vivo. Neuron 73:729-742.

Newbern JM, Li X, Shoemaker SE, Zhou J, Zhong J, Wu Y, Bonder D, Hollenback S, Coppola G, Geschwind DH, Landreth GE, Snider WD (2011) Specific functions for ERK/MAPK signaling during PNS development. Neuron 69:91-105.

Nguyên DT, Kebache S, Fazel A, Wong HN, Jenna S, Emadali A, Lee EH, Bergeron JJ, Kaufman RJ, Larose L, Chevet E (2004) Nck-dependent activation of extracellular signal-regulated kinase-1 and regulation of cell survival during endoplasmic reticulum stress. Mol Biol Cell 15:4248-4260.

Novoa I, Zeng H, Harding HP, Ron D (2001) Feedback inhibition of the unfolded protein response by GADD34-mediated dephosphorylation of eIF2alpha. J Cell Biol 153:1011-1022.

Ogata T, Iijima S, Hoshikawa S, Miura T, Yamamoto S, Oda H, Nakamura K, Tanaka S (2004) Opposing extracellular signal-regulated kinase and Akt pathways control Schwann cell myelination. J Neurosci 24:6724-6732.

Parkinson DB, Bhaskaran A, Droggiti A, Dickinson S, D’Antonio M, Mirsky R, Jessen KR (2004) Krox-20 inhibits Jun-NH2-terminal kinase/c-Jun to control Schwann cell proliferation and death. J Cell Biol 164:385-394.

Parkinson DB, Bhaskaran A, Arthur-Farraj P, Noon LA, Woodhoo A, Lloyd AC, Feltri ML, Wrabetz L, Behrens A, Mirsky R, Jessen KR (2008) c-Jun is a negative regulator of myelination. J Cell Biol 181:625-637.
Pennuto M, Tinelli E, Malaguti M, Del Carro U, D’Antonio M, Ron D, Quattrini A, Feltri ML, Wrabetz L (2008) Ablation of the UPR-mediator $\mathrm{CHOP}$ restores motor function and reduces demyelination in CharcotMarie-Tooth 1B mice. Neuron 57:393-405.

Rajesh K, Papadakis AI, Kazimierczak U, Peidis P, Wang S, Ferbeyre G, Kaufman RJ, Koromilas AE (2013) eIF2 $\alpha$ phosphorylation bypasses premature senescence caused by oxidative stress and pro-oxidant antitumor therapies. Aging (Albany NY) 5:884-901.

Ron D, Walter P (2007) Signal integration in the endoplasmic reticulum unfolded protein response. Nat Rev Mol Cell Biol 8:519-529.

Ryu EJ, Wang JY, Le N, Baloh RH, Gustin JA, Schmidt RE, Milbrandt J (2007) Misexpression of Pou3f1 results in peripheral nerve hypomyelination and axonal loss. J Neurosci 27:11552-11559.

Sanmaneechai O, Feely S, Scherer SS, Herrmann DN, Burns J, Muntoni F, Li J, Siskind CE, Day JW, Laura M, Sumner CJ, Lloyd TE, Ramchandren S, Shy RR, Grider T, Bacon C, Finkel RS, Yum SW, Moroni I, Piscosquito $\mathrm{G}$, et al. (2015) Genotype-phenotype characteristics and baseline natural history of heritable neuropathies caused by mutations in the MPZ gene. Brain 138:3180-3192.

Scheuner D, Song B, McEwen E, Liu C, Laybutt R, Gillespie P, Saunders T, Bonner-Weir S, Kaufman RJ (2001) Translational control is required for the unfolded protein response and in vivo glucose homeostasis. Mol Cell 7:1165-1176.

Scheuner D, Vander Mierde D, Song B, Flamez D, Creemers JW, Tsukamoto K, Ribick M, Schuit FC, Kaufman RJ (2005) Control of mRNA translation preserves endoplasmic reticulum function in beta cells and maintains glucose homeostasis. Nat Med 11:757-764.

Shapiro L, Doyle JP, Hensley P, Colman DR, Hendrickson WA (1996) Crystal structure of the extracellular domain from P0, the major structural protein of peripheral nerve myelin. Neuron 17:435-449.

Sidoli M, Musner N, Silvestri N, Ungaro D, D’Antonio M, Cavener DR, Feltri ML, Wrabetz L (2016) Ablation of Perk in Schwann cells improves myelination in the S63del Charcot-Marie-Tooth 1B mouse. J Neurosci 36:11350-11361.

Topilko P, Schneider-Maunoury S, Levi G, Baron-Van Evercooren A, Chennoufi AB, Seitanidou T, Babinet C, Charnay P (1994) Krox-20 controls myelination in the peripheral nervous system. Nature 371:796-799.

Vincent AM, Kato K, McLean LL, Soules ME, Feldman EL (2009) Sensory neurons and Schwann cells respond to oxidative stress by increasing antioxidant defense mechanisms. Antioxid Redox Signal 11:425-438.

Volpi VG, Touvier T, D’Antonio M (2017) Endoplasmic reticulum protein quality control failure in myelin disorders. Front Mol Neurosci 9:162.

Volpi VG, Ferri C, Fregno I, Del Carro U, Bianchi F, Scapin C, Pettinato E, Solda T, Feltri ML, Molinari M, Wrabetz L, D’Antonio M (2019) Schwann cells ER-associated degradation contributes to myelin maintenance in adult nerves and limits demyelination in CMT1B mice. PLoS Genet 15:e1008069.

Wrabetz L, D'Antonio M, Pennuto M, Dati G, Tinelli E, Fratta P, Previtali S, Imperiale D, Zielasek J, Toyka K, Avila RL, Kirschner DA, Messing A, Feltri ML, Quattrini A (2006) Different intracellular pathomechanisms produce diverse Myelin Protein Zero neuropathies in transgenic mice. J Neurosci 26:2358-2368.

Wu J, Rutkowski DT, Dubois M, Swathirajan J, Saunders T, Wang J, Song B, Yau GD, Kaufman RJ (2007) ATF6alpha optimizes long-term endoplasmic reticulum function to protect cells from chronic stress. Dev Cell 13:351-364.

Yamamoto K, Sato T, Matsui T, Sato M, Okada T, Yoshida H, Harada A, Mori K (2007) Transcriptional induction of mammalian ER quality control proteins is mediated by single or combined action of ATF6alpha and XBP1. Dev Cell 13:365-376

Yoshida H, Okada T, Haze K, Yanagi H, Yura T, Negishi M, Mori K (2000) ATF6 activated by proteolysis binds in the presence of NF-Y (CBF) directly to the cis-acting element responsible for the mammalian unfolded protein response. Mol Cell Biol 20:6755-6767.

Yoshida H, Matsui T, Yamamoto A, Okada T, Mori K (2001) XBP1 mRNA is induced by ATF6 and spliced by IRE1 in response to ER stress to produce a highly active transcription factor. Cell 107:881-891. 